\title{
Extraction of Value-Added Minerals from Various Agricultural, Industrial and Domestic Wastes
}

\author{
Virendra Kumar Yadav ${ }^{1}\left(\mathbb{D}\right.$, Krishna Kumar Yadav ${ }^{2}\left(\mathbb{D}\right.$, Vineet Tirth ${ }^{3,4}{ }^{(D}$, Govindhan Gnanamoorthy ${ }^{5}$, \\ Nitin Gupta ${ }^{6} \mathbb{D}$, Ali Algahtani ${ }^{3,4} \mathbb{D}$, Saiful Islam ${ }^{7}\left(\mathbb{D}\right.$, Nisha Choudhary ${ }^{6}$, Shreya Modi ${ }^{8}$ and Byong-Hun Jeon ${ }^{9, *}(\mathbb{D}$
}

check for

updates

Citation: Yadav, V.K.; Yadav, K.K.; Tirth, V.; Gnanamoorthy, G.;

Gupta, N.; Algahtani, A.; Islam, S.; Choudhary, N.; Modi, S.; Jeon, B.-H. Extraction of Value-Added Minerals from Various Agricultural, Industrial and Domestic Wastes. Materials 2021, 14, 6333. https://doi.org/10.3390/ ma14216333

Academic Editor: Franco Medici

Received: 10 September 2021

Accepted: 16 October 2021

Published: 23 October 2021

Publisher's Note: MDPI stays neutral with regard to jurisdictional claims in published maps and institutional affiliations.

Copyright: (C) 2021 by the authors. Licensee MDPI, Basel, Switzerland. This article is an open access article distributed under the terms and conditions of the Creative Commons Attribution (CC BY) license (https:// creativecommons.org/licenses/by/ $4.0 /)$.
1 Department of Microbiology, School of Sciences, P P Savani University, Kosamba, Surat 394125, Gujarat, India; yadava94@gmail.com

2 Faculty of Science and Technology, Madhyanchal Professional University, Ratibad, Bhopal 462044, India; envirokrishna@gmail.com

3 Mechanical Engineering Department, College of Engineering, King Khalid University, Abha 61411, Asir, Saudi Arabia; vtirth@kku.edu.sa (V.T.); alialgahtani@kku.edu.sa (A.A.)

4 Research Center for Advanced Materials Science (RCAMS), King Khalid University, Guraiger, Abha 61413, Asir, Saudi Arabia

5 Department of Inorganic Chemistry, University of Madras, Chennai 660025, Tamil Nadu, India; gnanadrdo@gmail.com

6 School of Nanosciences, Central University of Gujarat, Gandhinagar 382030, Gujarat, India; nitinkgupta1988@gmail.com (N.G.); nishanaseer03@gmail.com (N.C.)

7 Civil Engineering Department, College of Engineering, King Khalid University, Abha 61413, Asir, Saudi Arabia; sfakrul@kku.edu.sa

8 Department of microbiology, Shri Sarvajanik Science College, Mehsana 384001, Gujarat, India; shreyamodi20@gmail.com

9 Department of Earth Resources and Environmental Engineering, Hanyang University, Seoul 04763, Korea

* Correspondence: bhjeon@hanyang.ac.kr

\begin{abstract}
Environmental pollution is one of the major concerns throughout the world. The rise of industrialization has increased the generation of waste materials, causing environmental degradation and threat to the health of living beings. To overcome this problem and effectively handle waste materials, proper management skills are required. Waste as a whole is not only waste, but it also holds various valuable materials that can be used again. Such useful materials or elements need to be segregated and recovered using sustainable recovery methods. Agricultural waste, industrial waste, and household waste have the potential to generate different value-added products. More specifically, the industrial waste like fly ash, gypsum waste, and red mud can be used for the recovery of alumina, silica, and zeolites. While agricultural waste like rice husks, sugarcane bagasse, and coconut shells can be used for recovery of silica, calcium, and carbon materials. In addition, domestic waste like incense stick ash and eggshell waste that is rich in calcium can be used for the recovery of calcium-related products. In agricultural, industrial, and domestic sectors, several raw materials are used; therefore, it is of high economic interest to recover valuable minerals and to process them and convert them into merchandisable products. This will not only decrease environmental pollution, it will also provide an environmentally friendly and cost-effective approach for materials synthesis. These value-added materials can be used for medicine, cosmetics, electronics, catalysis, and environmental cleanup.
\end{abstract}

Keywords: waste; agricultural waste; value-added materials; calcium oxide; eggshell; incense sticks

\section{Introduction}

Every day we come across various types of waste in our life either in houses, working areas, industries, farms, etc. These waste materials can be kitchen waste, agricultural waste, industrial waste, or poultry waste. Although there are also several other types of waste, they are outside the scope of the present study. The waste produced in our houses, such as kitchen waste and incense stick ash can be categorized as household waste [1], whereas the waste produced from the agricultural practices, such as wheat straw [2,3], wheat husks [4], 
rice straw [5], rice husks [6], coconut shells [7], palms and dates [8], lemon peel [9], almond shells [10], etc., can be considered to be agricultural waste [11]. The waste generated by industry, such as coal fly ash (CFA) [12,13], red mud [14,15], gypsum waste [16,17], sewage sludge [18], iron tailing [19], etc., fall under the category of industrial waste [20]. Eggshells [21-23] and poultry litter [24,25] can be categorized as poultry waste; however, most investigators have considered eggshells to also belong to industrial waste. Among the above-mentioned types of waste, agricultural and industrial wastes raise major concerns for the environment, as millions of tons are produced every year around the world. Most of these waste materials are still disposed of via landfill [26,27], dumping, or disposal in water, creating pollution of the environment. The dumping of such waste may further deteriorate fertile agricultural soil [28], produce a foul odor [29] that may attract pests and mosquitos, and lead to health issues for human beings and animals [30]. Some types of industrial waste, like CFA [31] and red mud [32], are considered hazardous because of their high concentration of toxic heavy metals [33]. Heavy metals from dumping areas can leach into the surrounding soil, and when it rains, they may percolate into water bodies, thus leading to water pollution [34].

Nowadays, with the advent of new technologies, such waste can be processed into value-added minerals, especially in metallurgy. They can also be applied in the fields of agriculture [35], adsorbents [36,37], geo-polymers [38,39], ceramics [40], and environmental cleanup [41]. This article reviews and discusses a variety of waste materials in detail, including silica, alumina, calcium oxides, carbonates, etc., along with their properties, applications, and methods for their recovery.

\section{Industrial Waste}

Waste can be classified into several classes depending on its origin, for instance, industrial waste (CFA, paper and pulp waste), agricultural waste (coconut coir, sugarcane bagasse, and lemon peel) [42-49]. Similarly, waste materials produced in the home are referred to as domestic waste, including kitchen waste and incense stick ash, while eggshells and waste from poultry are regarded as poultry waste. The major categories of waste are shown below in Figure 1.

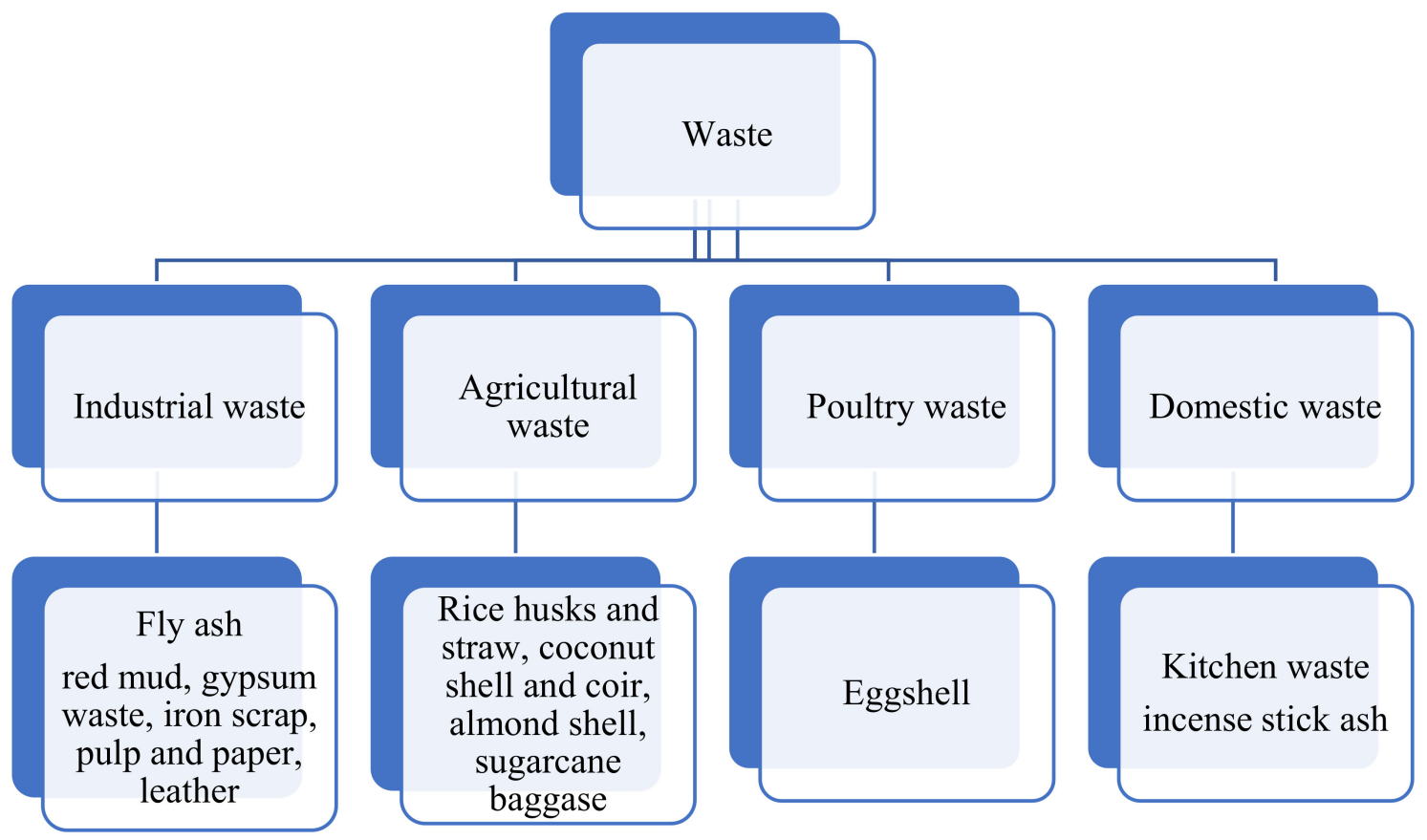

Figure 1. Classifications of the different valuable waste materials. 
Industrial waste refers to byproducts, e.g., CFA, red mud, gypsum waste, and other municipal waste, generated in the industrial sector. Among the various types of waste, this is one of the major sources that requires special attention due to its hazardous nature.

\subsection{Fly Ash}

Coal fly ash consists of fine powders produced from the pulverized coal used in the thermal power plants during the generation of electricity. It is heterogeneous in nature, and is made up of a glassy amorphous phase and a crystalline quartz phase, such as mullite and magnetite. Fly ash is produced in large amounts in TPPs, and is mainly considered waste, although its mineral value makes it a useable material.

\subsubsection{Recovery of Minerals from CFA}

CFA can be applied in several ways in the fields of agriculture, remediation (as an economical adsorbent), ceramics, etc. [50]. Formerly, CFA was considered a hazardous waste [51], but today, it is considered to be a useable material. CFA has high amounts of micro- and macro-nutrients that can be used as a source of nutrients for plants [52,53]. It is used in agriculture (as a fertilizer) [54], forestation [55], reclamation of wasteland [56], and for maintaining the $\mathrm{pH}$ of acidic soil [56]. CFA is also used as an adsorbent for the removal of pollutants-mainly dyes [57,58], pesticides [57,58], and heavy metals [59,60] - from wastewater. It is used for making nanocomposites [61] that are applicable in the defense industry $[62,63]$ and the production of lightweight materials $[64,65]$. CFA can be used for making blended cement [66] tiles, bricks [67], blocks [56], RCC, kitchen panels, and geo-polymers. CFA can also be used as fillers in rubbers and tires [68], and can also be used in the mining industry [56,69] for the recovery of ferrous metals [70], cenospheres [55], mullite [71], silica [72], zeolites [73], and alumina. It can also be applied for the recovery of unburnt carbon, soot, and carbon nanomaterials like carbon nanotubes, fullerenes, and graphene. These carbonaceous materials are formed due to the burning of the organic content of the coal, while soot and unburnt carbon are due to the incomplete burning of coal. Higher grades of coal like anthracite and bituminous coal have higher carbon contents, so after the burning of such coals in thermal power plants, the resulting ash will also have a high content of carbon in the form of unburnt carbon, soot, and carbon nanomaterials like carbon nanotubes, fullerene, etc.

Silica

Silica accounts for up to $40-60 \%$ of CFA [74], depending on the source of the CFA, the type of coal, the operating parameters of the thermal power plant, the furnace temperature, etc. Silica is present in CFA in either crystalline or amorphous form [75]. The crystalline form of silica is present mainly as quartz, sillimanite, and mullite [76], whereas the glassy amorphous form is the only form of amorphous silica. Crystalline silica is mainly inert, and does not easily react with acids or bases. Therefore, silica can only be extracted from the amorphous form, as it reacts easily with strong bases. In addition, silica can easily be extracted from CFA through treatment with strong bases like $\mathrm{NaOH}, \mathrm{KOH}$, and sodium bicarbonate [77]. Silica is mainly extracted using either the alkali treatment [78] method or the alkali fusion method [79]. The complete extraction of silica using the alkali treatment method is depicted in Figure 2, while in alkali fusion method, the silica source is calcinated with $\mathrm{NaOH}$ at high temperature in order to form a new mineral (such as nephaline), from which it is easier and more efficient to extract the silica. Yadav et al. reported the extraction of nanosilica from fly ash tiles using the alkali fusion method [80]. Silica can be used in the production of glass and ceramics [80], in drug delivery [81], and used in medicine, foundries, adsorbents, catalytic processes [82], and molecular sieves [83]. Silica is nontoxic and mesoporous, meaning it can be readily used in various industries. The silica extracted from the CFA is nanosized (20-60 nm), but aggregates together to form lumps. 


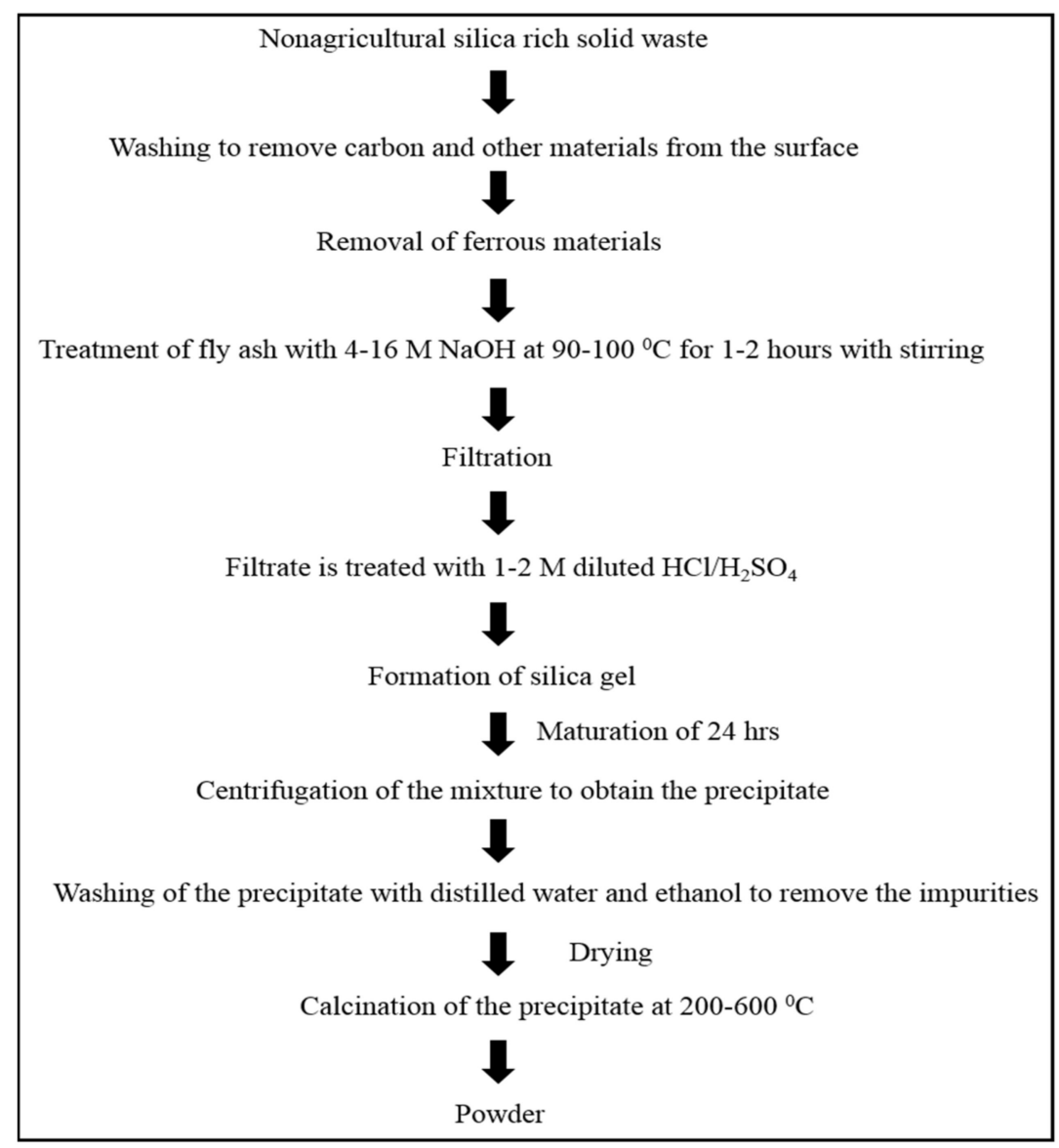

Figure 2. Schematic diagram of the synthesis of silica from silica-rich waste materials.

\section{Alumina}

Alumina, which is amphoteric in its nature, can be obtained from CFA or other alumina-rich materials using both acids and bases. Depending on the CFA type and the source of the coal, the alumina content in CFA can range between 20 and 40\% [84]. In CFA, alumina can mostly be found in the form of crystalline aluminosilicates [85] such as mullite. These aluminates are highly inert, and rarely react with acids; thus, only low yields can be obtained. They can be treated with strong mineral acids that can be directly converted to powder by thermal decomposition. They can also be extracted using alkali like $\mathrm{NaOH}$ at high temperatures, i.e., $125-1100{ }^{\circ} \mathrm{C}$. Alumina forms in numerous meta-stable phases, including gamma $[\gamma]-$, epsilon $[\eta]-$, delta $[\mathrm{d}]-$, theta $[\theta]-$, kappa $[\mathrm{k}]-$ and $\chi$-alumina. While the most stable phase of alumina is [a] alpha. Of all of the phases, the gamma-phase of alumina is the most important and widely used nanosized material. Gamma alumina is widely used in the petroleum and automobile industries as a catalyst and catalyst substrate, to produce ceramics [86] and glass, adsorbents, spacecraft materials, microelectronics, thermal-resistant materials, and as a coating material for thermal wear and abrasives [87], optoelectronics, and metallurgy. Alumina nanoparticles have high compression strength, high chemical resistance, a high degree of refractoriness, high thermal shock resistance, high abrasion strength, and high dielectric strength. Alumina is also applied in ceramics, adsorbents, fire-retardant materials, acid, and alkali-resistant materials [88].

\section{Cenospheres}

Cenospheres are aluminosilicate spheres [89,90], the size of which varies by microns. They are lightweight nanostructured materials that are created when coal is combusted within a furnace. These are used as lightweight materials for aircraft, in the field of defense, in fire-proof materials [55], and for acid and alkali wear-resistant materials [91]. Today, 
cenospheres that are tiny hollow spheres with diameter of approximately 10-1000 $\mu \mathrm{m}$ are among the most desirable byproducts that can be obtained from coal combustion processes. They normally comprise $1-2 \%$ of CFA obtained during the process of coal combustion. Cenospheres possess properties such as very high mechanical strength and low density; thus, they are regarded as a highly significant issue in coal-fired power plants. A number of parameters affect cenosphere properties, including the grinding operations, the nature of the coal used, the combustion parameters, and withdrawal when generating electricity. These materials are mainly possess a glassy surface and a crystalline matrix such as mullite with a nano-film covering with a thickness of 30-50 nm. Their form is similar to that of a shell, with a thickness varying between 2 and 30 microns. They are extracted using the density-based centrifugation method, during which finer lightweight cenospheres float at the top of the slurry, while the particles of heavier ferrous metals settle at the bottom [55]. The cenospheres are collected from the top and dried before use. The formation mechanism of cenospheres during pulverized coal combustion is complex and is highly dependent on fuel properties and combustion parameters. The formation mechanism of cenospheres is very similar to the procedure of glass blowing [92]. Therefore, it would be beneficial to take a closer look into glass formation principles.

The literature presents two approaches for the extraction of cenospheres from fly ash, namely dry separation and wet separation. The conventional cenosphere extraction method is primarily performed using wet processes, namely simple sedimentation and flotation [93]. There are two methods for estimating the degree of separation when recovering cenospheres from coal CFA, namely the float method and the sink method. To separate cenospheres from CFA, various liquids, viz., water $(1 \mathrm{~g} / \mathrm{cc})$ and acetone $(0.789 \mathrm{~g} / \mathrm{cc})$, can be used. Fly ash is kept in a vessel and water is added to it. The complete mass is stirred for four hours; afterwards, it is allowed to settle for ten hours. Then, all cenospheres with densities lower than $1 \mathrm{~g} / \mathrm{cc}$ will float up and can be separated [94].

Mullite

Mullite, consisting of micron-sized particles (1-1.5 microns in length and $0.3-0.5$ microns in width), is a rarely observed crystalline mineral that contains aluminum silicate $\left(3 \mathrm{Al}_{2} \mathrm{O}_{3}\right.$ $2 \mathrm{SiO}_{2}$ ) [95] and is mainly made up of $\mathrm{Al}, \mathrm{Si}$, and $\mathrm{O}$; however, its composition can be quite variable. In the process of combusting aluminosilicate raw materials, mullite is created. This material is a key component in porcelains, ceramic whiteware, high temperature insulation, refractory materials and traditional ceramics [96]. Mullite is a compositional orthorhombic aluminosilicate, and generally possesses the composition $\mathrm{Al}_{2}\left(\mathrm{Al}_{2+2 x} \mathrm{Si}_{2-2 x}\right) \mathrm{O}_{10-x}$. Mullites are non-stoichiometric compounds whose structure is similar to magnetite containing impurities. It is rarely formed in nature, because of its formation conditions, which require high temperature in combination with low pressure. Synthesis of mullites is possible from high-silico-aluminous CFA only, as they are rich in silica and alumina, with lower contents of iron oxides. Iron oxides have a negative effect on mullite. Generally, for the purpose of synthesizing mullites from CFA, cenospheres are the most effective materials, since they have lower contents of iron oxides.

Mullites are formed in CFA from the organic and inorganic materials present in coal as a result of different melting and firing processes. After the extraction of mullites using a hydrofluoric process, it can be characterized by XRD and SEM-EDS in CFA. A clearer picture of mullite can be obtained using XRD and NMR. Both of these techniques can be used to efficiently investigate the value of $x$ and the oxygen hole rate in the general formula, thus obtaining the mullite composition. Mullites can be used as refractory materials because of their high melting point $\left(1840^{\circ} \mathrm{C}\right)$.

Mullites are aluminosilicate minerals with the general formula $\mathrm{Al}_{4+2 x} \mathrm{Si}_{2+2 \mathrm{x}} \mathrm{O}_{10-x}$ (with the value of $x$ varying between 0.17 and 0.59 ). Mullites are capable of forming two stoichiometric forms, namely $3 \mathrm{Al}_{2} \mathrm{O}_{3} 2 \mathrm{SiO}_{2}$ and $2 \mathrm{Al}_{2} \mathrm{O}_{3} \mathrm{SiO}_{2}$. Mullite is known to be the only stable binary phase of the $\mathrm{A}_{2} \mathrm{O}_{3}-\mathrm{SiO}_{2}$ system that exists under ambient conditions. From an empirical perspective, its chemical compositions include $71.8 \mathrm{wt} \%$ 
$\mathrm{A}_{2} \mathrm{O}_{3}$ and $28.2 \mathrm{wt} \% \mathrm{SiO}_{2}$, designated as 3/2-mullite $\left(3 \mathrm{~A}_{2} \mathrm{Oy}_{2} \mathrm{SiO}_{2}\right)$. Mullite has two common morphologies: a platelet shape and a needle shape. In the platelet shape, it has a low aspect ratio, whereas in the needle shape, it possesses a high aspect ratio. In addition, mullite has low thermal conductivity, low thermal expansion, high thermal stability, high corrosion stability, high strength, and high fracture toughness. It has excellent creep resistance, acceptable thermal shock and stress resistance, and acceptable strength wear resistance, and it can be used at high temperatures. Mullites can be applied as an effective replacement for platinum in diesel engines, furnace liners, electrical insulators, protection tubes, kiln furniture, rollers, heat exchanger components, heat insulation parts, pressed parts, and isostatically pressed parts [97-100].

Yadav et al., 2021 reported the recovery of needle-shaped mullite, $90-300 \mathrm{~nm}$ in size, extracted from CFA using $16 \mathrm{M} \mathrm{HF}$ acid. An optimum ratio of CFA and HF was mixed and kept for interaction in an incubator shaker. The CFA was collected from the Gandhinagar and Gujarat thermal power plants. The source of the coal was anthracite/bituminous coal, i.e., higher grades of coal. The detailed mechanism for recovery of mullites from CFA is given below in Figure 3 [94].

Separation of ferrous fractions from fly ash slurry

using a permanent neodymium magnet

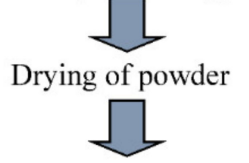

Dissolution of fly ash by diluted HF: $100 \mathrm{mg}+2.5$

$\mathrm{mL}(\mathrm{HF})(3 \%)$ in a plastic bottle

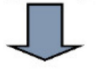

Stirring for 15 hours at room temperature

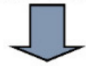

Decantation of solution after 15 hours

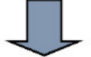

Centrifugation/filtration to obtain the residue

at variable rpm for 5-10 minutes

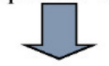

Washing of residue with excess of water

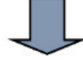

Washing of residue with dilute $\mathrm{HCl}(4 \mathrm{~N})$

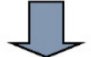

Washing of residue with dilute $\mathrm{HNO}_{3}(4 \mathrm{~N})$

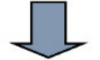

Washing of residue with dilute EDTA (4N)

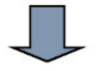

Washing of all residues at $\mathrm{pH} 7$ and 9

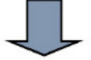

Weighing of the residue, and weight loss noticed

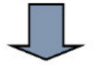

Analysis by XRD, SEM, and FTIR

Figure 3. Schematic diagram for the recovery of mullite from CFA adopted from Yadav et al., open access journal Crystals, 2021 [94]. 


\section{Zeolites Synthesis from CFA}

Zeolites are another class of materials that are widely used in industry for petroleum cracking, cation exchange resins, water softening processes, etc. These zeolites are also hydrates of alumina and silica, mainly containing $\mathrm{Al}$, $\mathrm{Si}$, cations from gp II $(\mathrm{Ca}, \mathrm{Mg}, \mathrm{Na})$ and water molecules. Due to the presence of $40-60 \%$ silica and $20-40 \%$ alumina, the CFA serves as an economical resource for zeolite material synthesis. To date, zeolites have been synthesized from CFA by using $4-8 \mathrm{M}, \mathrm{NaOH}$ treatment along with continuous heating at $90-105{ }^{\circ} \mathrm{C}$, for $1 \mathrm{~h}$ to $24 \mathrm{~h}$ with rigorous stirring. The $\mathrm{pH}$, temperature, heating and stirring time decides the morphology and class of zeolites to be synthesized. There are several reports in the literature in which CFA from different parts of the globe has been used for the synthesis of zeolites. Yadav et al., 2019 and 2021, reported the synthesis of zeolites from CFA collected from the Gandhinagar and Gujarat TPPs in India. The size of the synthesized zeolites varied between $80 \mathrm{~nm}$ and $180 \mathrm{~nm}$ in width, while their length varied from $120 \mathrm{~nm}$ to $300 \mathrm{~nm}$ [99].

\section{2. $\operatorname{Red} M u d$}

Red mud is a hazardous byproduct of the bauxite industry [101], and is produced at the time of extraction of alumina from bauxite using Bayer's method [102]. It is considered hazardous because of its high alkalinity and the presence of various toxic heavy metals; however, it is also a rich source of titanium, iron, and aluminum (composition is shown in Table 1). In addition, red mud is recognized as a bauxite residue [103], as it is what is left after the extraction of all the extractable alumina from bauxite. The resulting mud is a mixture of the insoluble fraction of solid and metallic oxides, and ore, which remains after the extraction of the aluminum-containing components [104]. It is typically disposed of as a slurry with a solid concentration ranging between 10 and $30 \%, \mathrm{pH}$ in the range of 13, and high ionic strength [14]. This disposal problem is compounded by the fact that typical bauxite processing produces up to three times as much toxic red mud as aluminum. Figure 4 shows a typical SEM micrograph of red mud. The particles of red mud aggregate together to form lumps.

Table 1. Elemental composition of red mud.

\begin{tabular}{cc}
\hline Composition & Percentage \\
\hline $\mathrm{Fe}_{2} \mathrm{O}_{3}$ & $30-60 \%$ \\
$\mathrm{Al}_{2} \mathrm{O}_{3}$ & $10-20 \%$ \\
$\mathrm{SO}_{2}$ & $3-50 \%$ \\
$\mathrm{Na}_{2} \mathrm{O}$ & $2-10 \%$ \\
$\mathrm{CaO}$ & $2-8 \%$ \\
$\mathrm{TiO}_{2}$ & $2-5 \%$ \\
\hline
\end{tabular}

Approximately 44 million tons [MTs] of primary aluminum are produced annually around the world [105]; by that count, roughly 132 MTs of red mud enter retention ponds and some dry stack tailing areas annually [106]. The alumina plants in the Indian context have an annual capacity of $1.692 \mathrm{MTs}$; they produce $0.6 \mathrm{MTs}$ of metal, and approximately 2 MTs of red mud per year [107]. The chemical analysis of RM reveals the presence of silica, aluminum, iron, calcium, and titanium, as well as an array of minor constituents, namely $\mathrm{Na}, \mathrm{K}, \mathrm{Cr}, \mathrm{V}, \mathrm{Ni}, \mathrm{Ba}, \mathrm{Cu}, \mathrm{Mn}, \mathrm{Pb}, \mathrm{Zn}$, etc. [15,108]. There is a high variance in chemical composition among various red muds generated around the world [14]. 


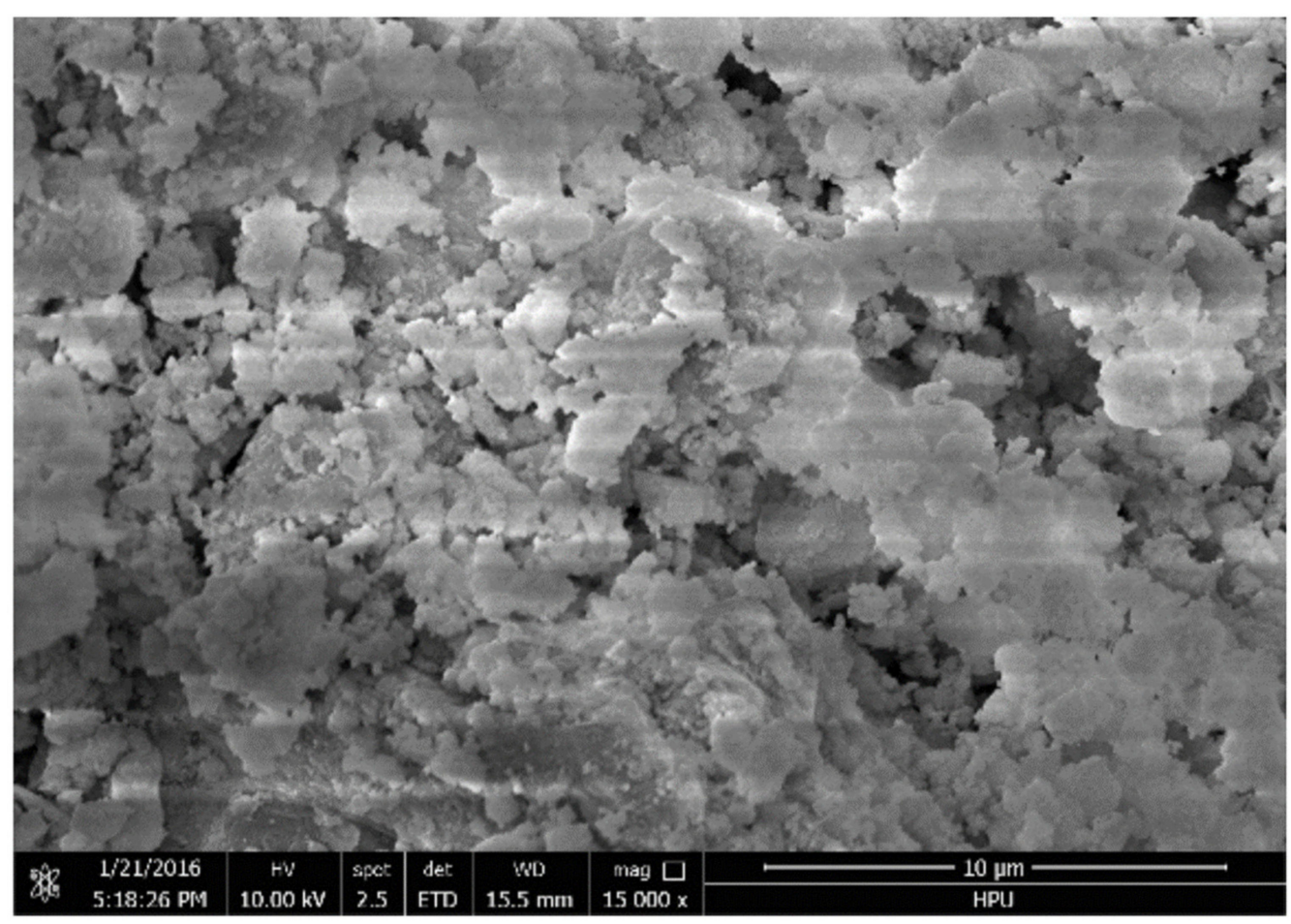

Figure 4. SEM micrograph of red mud, adopted from Zhang et al., open access journal Applied Sciences, 2018 [109].

Currently, in the alumina industry, alumina is obtained by carrying out Bayer's process on bauxite. The byproduct of such processes is red mud, which is generally regarded as dangerous waste, because it contains high concentrations of some heavy metals, iron oxide, and other metal oxides. Industry does not recycle it, and there is no available disposal method for it. Currently, companies collect this waste in their vicinity after the extraction of alumina. This continuous piling up of red mud constitutes a major and global threat to the environment $[110,111]$. This red mud contains high amounts of iron oxides and heavy metals, which can leach out into water bodies and cause damage to aquatic fauna. In India, two major alumina-producing companies are NALCO and HINDALCO, who generate a huge amount of waste every year in the form of red mud. This causes water pollution through its entry into water streams, leaching toxic heavy metals into water bodies. This also affects the aquatic flora and fauna. In addition, it has adverse effects on the biological oxygen demand (BOD) and chemical oxygen demand (COD) of the water bodies, resulting in a lowering of these parameters. This waste changes the community structure of water bodies. The alkalinity of water bodies is increased as a result of releasing $\mathrm{NaOH}$ into the water. In any alumina refinery, large amounts of land are required for the handling of this waste.

\subsubsection{Recovery of Alumina from Red Mud}

The red mud-based recovery of alumina involves several steps in series-recovery of ferrous particles, leaching of dried red mud with strong mineral acids, filtration to obtain the filtrate, crystallization of the leachate, the recovery of acids, and finally calcination-in order to obtain the alumina powder. A complete flow chart depicting the extraction of alumina from red mud is given below in Figure 5 . 


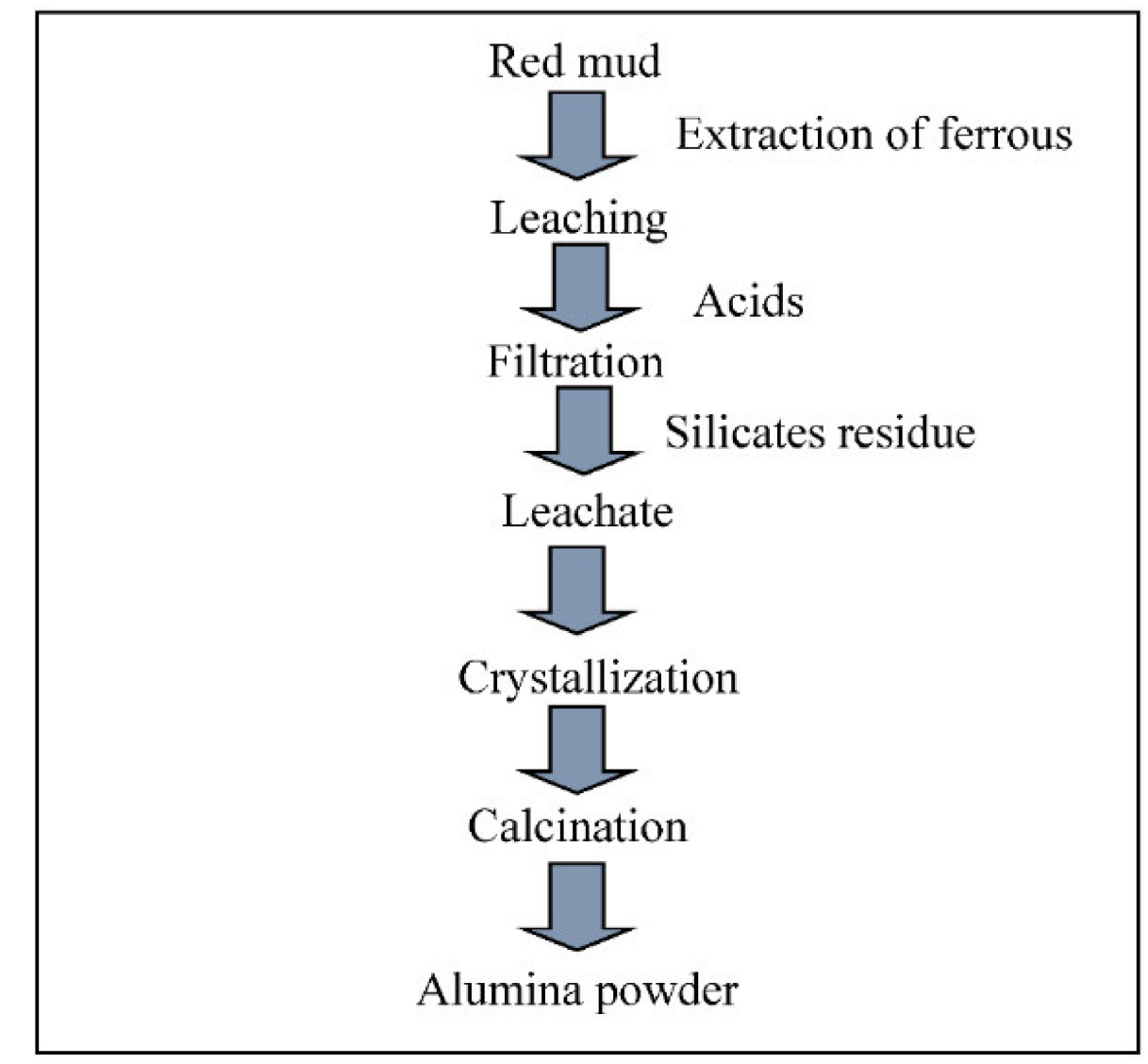

Figure 5. Flow chart for the recovery of alumina from red mud/CFA.

The recovery of alumina and ferric oxides from iron-rich red mud has been reported using the reduction sintering technique [112]. Different experiments have shown that up to $89.71 \%$ of alumina can be extracted, with a Fe recovery rate of $60.67 \%$, under optimal conditions [113]. Zhang et al. [114] investigated andradite-grossular hydrogarnet formation in the hydrothermal process with the aim of examining its effect on alumina and alkali recovery from Bayer red mud. For the evaluation of the parameters with the highest impact on the recovery process, they took into consideration the batch experiments and parameters such as caustic ratio (molar ratio of $\mathrm{Na}_{2} \mathrm{O}$ to $\mathrm{Al}_{2} \mathrm{O}_{3}$ in sodium solution), reaction temperature, residence time, and sodium concentration. Zhu et al. [115] reported the recovery of alumina and alkali from red mud using a novel calcification-carbonation method under mild reaction conditions. Batch experiments were performed, and the effects of temperature, pressure, and additive addition on the extraction efficiency of alumina were examined, and the extraction efficiency of alumina was 95.2\%. In another study, Meher [116] reported the extraction of alumina from red mud using a calcium carbonate and sodium carbonate sintering process. They studied the impacts of $\mathrm{Na}_{2} \mathrm{CO}_{3}$ and $\mathrm{CaCO}_{3}$ additives, sintering time and temperature, and leaching time on the effectiveness of alumina extracted from red mud. The alumina extraction was up to $97.64 \%$ at a sintering temperature of $1100{ }^{\circ} \mathrm{C}$ for $4 \mathrm{~h}$ with red mud.

\subsubsection{Applications of Red Mud}

Many studies have confirmed the benefits of red mud in the process of treating water and removing inorganic anions (e.g., fluoride, phosphate, and nitrate), toxic heavy metals and metalloid ions, as well as organic substances (e.g., phenolic compounds, dyes, and bacteria) $[117,118]$. Moreover, red mud can be employed as an effective catalyst in processes such as hydrocarbon oxidation, hydrodechlorination, and hydrogenation [119]. The broader areas of application of red mud are given in Figure 6. 


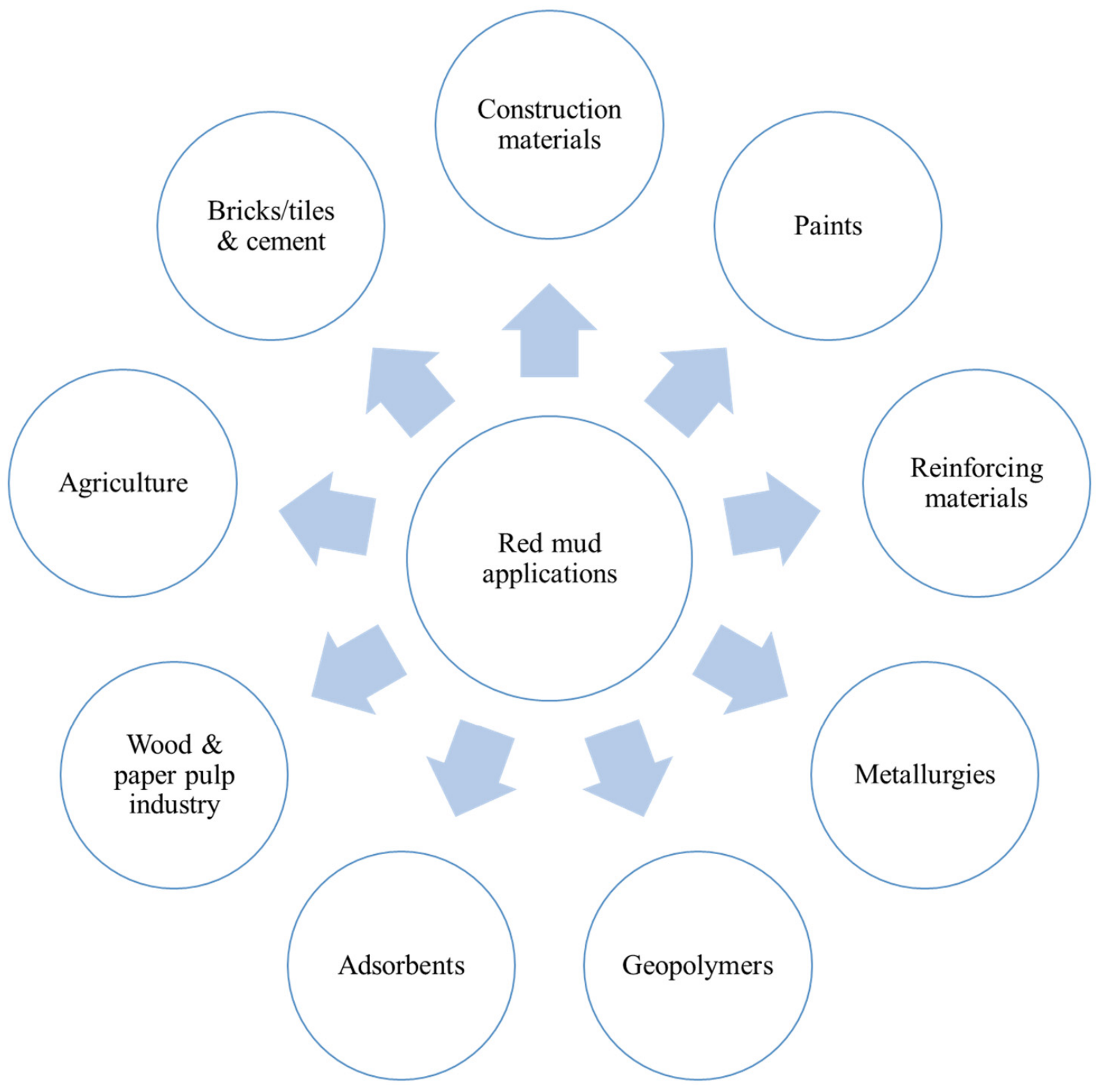

Figure 6. Diagrammatic representation of red mud in their broader applications.

\subsection{Iron Slags/Scraps}

There are several iron-based industries, like the steel industry, where iron particles are generated as waste materials [120]. These iron materials can be processed for the recovery of highly pure iron, zero-valent iron, or iron oxides. These can be used directly as filings or in coke industries [121]; thus, they have drawn much attention. These iron particles can be recovered using strong magnets in either wet or slurry form. These iron particles can further be treated with acids to obtain iron-rich leachates that can be used as precursor materials for the synthesis of different types of iron oxide particles. The synthesized iron oxide particles can be recovered by precipitation, chemical precipitation, and calcination. These iron oxides are so highly pure that they can act as an adsorbent in processes like the treatment of wastewater, environmental cleanup, in ceramics, and in the steel industry [122,123]. The major advantages of such iron oxide particles include their ability to be easily recovered from the reaction site, their recyclability, and their easy external manipulation using strong magnets [124]. The synthesis of iron oxide particles from waste is cost-effective and environmentally friendly. 
Tang et al. [125] attempted a coal-based smelting reduction method for the recovery of $\mathrm{Fe}, \mathrm{Ni}$, and $\mathrm{Cr}$ from pickling sludge waste. Their findings showed that the Fe recovery was $98.1 \%$ under optimized conditions. Tang et al. [126] reported the recovery of iron from iron ore tailings. They used it to develop a concrete composite mixture. They investigated the impacts of different parameters upon the extraction of ferrous particles. Up to $83.86 \mathrm{wt} \%$ of iron was recovered from a feed iron grade of $12.61 \mathrm{wt} \%$. Zhang et al. [127] attempted to recover iron from the waste slag of pyrite processing using a reduction roasting magnetic separation method. The iron content of the concentrate was initially $57 \%$, of which $87 \%$ was extracted using the aforementioned method. It should also be noted that, through further treatment using chlorinated segregation-magnetic separation, the iron content in the slag was increased to $83 \%$.

In the study carried out by Wang Yu et al. [128], the co-precipitation and magnetic separation methods were adopted with the aim of recovering iron from waste ferrous sulphate. They investigated the impacts of various reaction parameters on the iron recovery, and also examined the impacts of milling time and magnetic induction intensity on the separation of magnetic particles. The mixed magnetic particles were wet-milled for $20 \mathrm{~min}$ before magnetic separation. The grade and recovery rate of iron in the magnetic concentrate drastically increased from $51.41 \%$ to $62.05 \%$, and from $84.15 \%$ to $85.35 \%$, respectively.

\subsection{Gypsum Waste $\left(\mathrm{CaSO}_{4} \cdot 2 \mathrm{H}_{2} \mathrm{O}\right)$}

Gypsum waste is a byproduct of the gypsum industry. It is widely used in dental applications, with its disposal representing a potential threat to the environment [129]. There is a possibility that when disposing of gypsum waste in landfill, there might be a reaction between the gypsum and biodegradable waste, which may produce poisonous and odorous hydrogen sulfide gas $[130,131]$. Gypsum waste can be processed for the recovery of $\mathrm{CaS}$, which ultimately changes to calcium carbonate. A schematic diagram of the process of recovering calcium carbonate from gypsum waste is shown below in Figure 7, as reported by Yadav et al., 2021 [129].

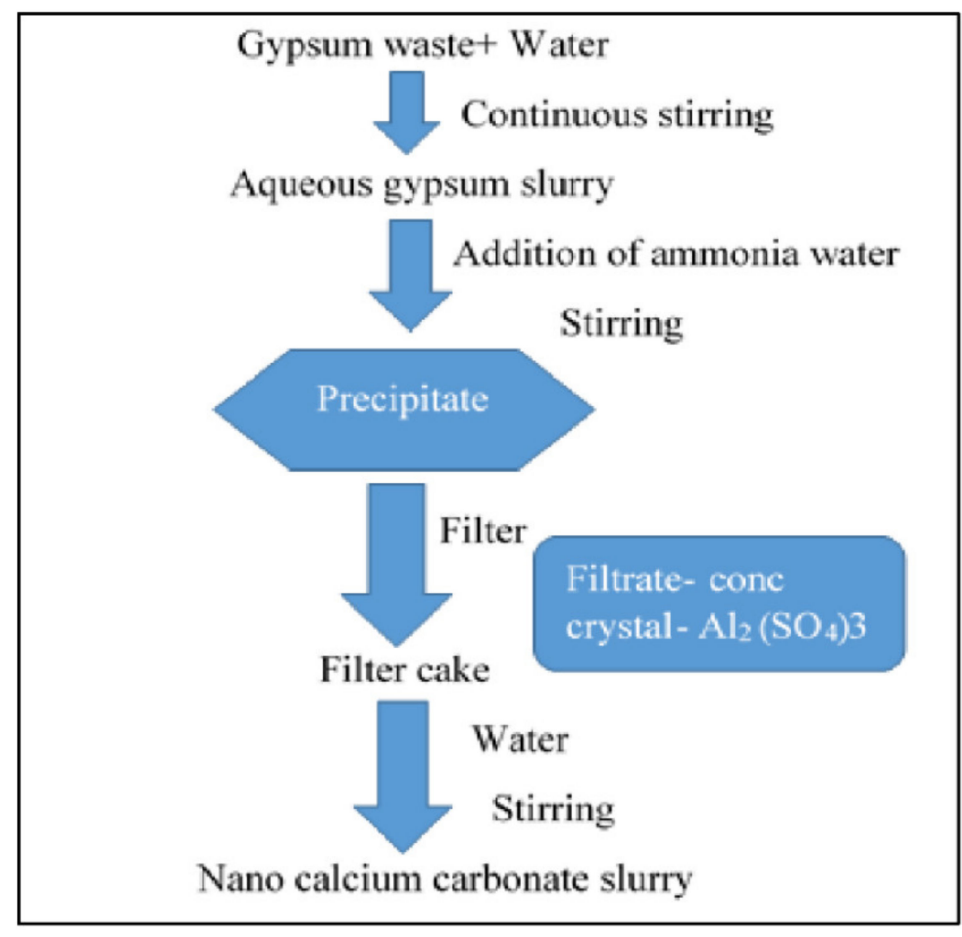

Figure 7. Steps involved in the synthesis of calcium carbonate nanoparticles from gypsum waste, adapted from Yadav et al., open access journal Applied Sciences, 2021 [129]. 
Beer et al. [132] attempted to synthesize calcium carbonate nanoparticles from gypsum waste, producing elemental sulfur as a byproduct. In this process, the first step was the thermal reduction of the gypsum waste into calcium sulfide $(\mathrm{CaS})$, followed by its direct aqueous carbonation, yielding low-grade carbonate products (i.e., 99 mass\% as $\mathrm{CaCO}_{3}$ ) or precipitated calcium carbonate (PCC). The carbonate product was found to be predominantly composed of calcite $(99.5 \%)$ with only $0.5 \%$ quartz. Calcite was the only $\mathrm{CaCO}_{3}$ polymorph obtained in the experimental process, while no vaterite or aragonite was found [133]. In addition, Mulopo and Radebe [129] investigated the batch recovery of calcium carbonate from gypsum waste slurry using sodium carbonate under ambient conditions. The results were applied to the pre-treatment of acid mine drainage (AMD) from coal mines. US patent no 2013/0288887 A1 reports a simple, cost-effective, and novel method for the recovery of nano-calcium carbonate from gypsum waste slurry [134]. Okumura et al. [135] extracted calcium oxide particles from the gypsum waste using reductive decomposition in a $\mathrm{CO}-\mathrm{CO}_{2}-\mathrm{N}_{2}$ atmosphere. They also investigated the reductive decomposition of spent $\mathrm{CaSO}_{4}$ using a packed-bed reactor. The $\mathrm{CaSO}_{4}$ was used for the production of calcium oxide. Ramachandran and Maniam [136] reported a two-step method comprising chemical and thermal reactions for the regeneration of calcium oxide from gypsum waste. The chemical changes and confirmation of the formation of calcium oxide were determined using XRD. Mbhele et al. [137] attempted to recover sulphur from gypsum waste using the following sequence of steps: (1) reduction of gypsum to $\mathrm{CaS}_{2}$ (2) stripping of the sulphide with carbon dioxide gas, and finally (3) the production of $S$.

\subsection{Agricultural Waste}

A great deal of solid agricultural waste is generated each year, presenting a major challenge for disposal processes, as it creates a foul odor and attracts pests, resulting in health issues for living beings. Some of the most commonly generated types of agricultural waste include rice husks [138], rice straw [139], wheat husks and straw, coconut shells [140], sugarcane bagasse [141], corn cobs, and almond shells. These types of agricultural waste are rich sources of carbon, silica, calcium, and other trace elements like $\mathrm{Fe}, \mathrm{Al}$, etc. Even today, only a small fraction of such agricultural waste is applied as a fuel, additive, and filler in the construction industry. A major fraction of agricultural waste is disposed of using three main techniques, thermal treatment, landfill, and decomposition, and these have been reported to negatively affect the environment [26]. For example, the thermal treatment of waste results in the release of numerous noxious gases like $\mathrm{CO}_{2}, \mathrm{CO}, \mathrm{Cn} \mathrm{Hm}$, SOx, NOx, ash, etc., many of which are classified as greenhouse gases. As a result, many scholars have raised objections over combustion as a method of agricultural waste disposal.

Agricultural waste such as sugarcane bagasse and rice husks constitute a rich source of silica. Both rice husks and sugarcane bagasse can act as potential candidates for silica extraction. The silica synthesized from such wastes can provide an alternative, renewable source, minimizing the pollution resulting from such materials. Meanwhile, coconut shell husks are a rich source of calcium [26]. The possibility of recovering of such valuable minerals from waste not only provides alternative precursor materials, it also provides an environmentally friendly, cost-effective approach to the problem. The use of such agricultural waste also minimizes environmental pollution. All of these waste products are biological materials; thus, they are rich sources of carbons that can be used for the synthesis of activated carbons or biochars.

There are certain plants that possess a high accumulation of silica in their leaves, stems, fruits, etc. The silica is taken up from the soil by the roots of the plants and distributed to the other plant parts. In plants, silica is mainly present as silicon. Silica can potentially be found in the solid waste used extensively in the industrial sector. Two factors, namely, the availability and quantity of silicon in the soil, affect silica deposition in agricultural residues [142]. Several plants consist of silica, includingwheat, rice, sunflowers, corn, and bamboo [143]. In general, silica can be extracted from leaves, stems, and other parts of a plant with a yield of between 0.1 and $10 \mathrm{wt} \%$. On the other hand, the quantity of silica 
in agricultural residues is dependent on the season, species, maturity, and geographical characteristics of the given farm.

\subsubsection{Rice Husks (RH) and the Recovery of Silica}

Rice husks are agricultural waste products that are produced during processing. During the hulling process, rice husks are obtained, which are mainly used as fodder for cattle. Rice husks and straw are major agricultural products, with an annual global production as high as one million tons. These waste products are common in rice-producing countries like India, Vietnam, and Japan. RH are rich is silica, but at the same time they also contain organic compounds that may interfere with the final purity of the silica. Therefore, $\mathrm{RH}$ have to first be calcinated at high temperature $\left(400-1000^{\circ} \mathrm{C}\right)$ in a muffle furnace. Furthermore, they have to be washed with phosphoric acid, which will remove the organic content. Once the $\mathrm{RH}$ ash is free from organic content, it is dried and treated with 4-16 $\mathrm{M} \mathrm{NaOH}$, along with $90-95^{\circ} \mathrm{C}$, for $60-90 \mathrm{~min}$ along with continuous stirring. $\mathrm{NaOH}$ will react with $\mathrm{NaOH}$ and will form sodium silicate, which will be further treated with 1-2 N HCl, resulting in silica gel. This silica gel is further washed and dried to obtain pure silica or nanosilica. Some authors have also reported calcination at $400-600{ }^{\circ} \mathrm{C}$ for 2-6 h in order to obtain nanosilica with the desired shaped [144].

\subsubsection{Sugarcane Bagasse and the Recovery of Silica}

Similarly, sugarcane bagasse is also one of the major byproducts of the sugarcane industry, and is produced after the extraction of sugarcane juice. Sugarcane bagasse is a rich source of carbohydrates and other minerals besides silica. It is also produced in huge quantities in sugar-producing countries. Sugarcane bagasse (SB) is considered to be a non-biodegradable solid material, and primarily consists of crystalline silica [145]. A major problem in the sugarcane industry is how to dispose of SB. At present, it is used in the production of ceramic tiles, soil fertilizers, and fodder in some parts of the world [146]. In comparison with other agricultural residues, sugarcane bagasse ash (SBA) possesses a very high quantity of silica. Table 2 presents the complete elemental composition of SBA. Several parameters affect the quantity of silica extractable from bagasse, including the nature of the soil, the surrounding environment, the harvesting process, and the time of harvesting.

Table 2. Elemental composition of sugarcane bagasse ash (SBA).

\begin{tabular}{ccc}
\hline Elements & Raw Sample & Sample after Acid Treatment \\
\hline $\mathrm{SiO}_{2}$ & 53.10 & 88.13 \\
$\mathrm{MgO}$ & 20.72 & 3.04 \\
$\mathrm{CaO}$ & 3.77 & 0.57 \\
$\mathrm{SO}_{3}$ & 11.20 & 4.69 \\
$\mathrm{P}_{2} \mathrm{O}_{5}$ & 7.36 & 1.15 \\
$\mathrm{~K}_{2} \mathrm{O}$ & 1.26 & 0.50 \\
\hline
\end{tabular}

Drummond et al. [147] reported silica extraction from different preparations of SBA by performing natural burning (SBA-NB) and laboratory burning (SBA-LP) at $700{ }^{\circ} \mathrm{C}$ for two hours using muffle furnace, which was followed by alkaline extraction. The experiments revealed that silica extraction of about $94.47 \%$ was achieved using natural burning, and $96.93 \%$ of the silica was obtained using laboratory burning. In another project, Harish et al. [148] attempted to recover silica from SBA and silica fumes as low-cost precursors for the synthesis of silica gel using a sodium hydroxide-based alkali treatment method. Norsuraya et al. [149] reported the synthesis of Santa Barbara Amorphous-15 from SBA. XRF revealed that raw sugarcane ash contained $53.10 \%$ silica, while acid-treated ash contained $88.13 \%$ silica.

Channoy et al. [141] conducted a study aiming to synthesize silica gel from SBA by treating the ash with $1.5,2$, and $2.5 \mathrm{~N} \mathrm{NaOH}$. The particle size of the obtained silica gel 
varied, with values of 120,100, and $80 \mathrm{~nm}$, respectively, as confirmed by SEM. SEM revealed that as the concentration of $\mathrm{NaOH}$ increased, the particle size decreased. Rovani et al. [150] made use of SBA waste to synthesize highly pure silica with a high adsorption capacity. The synthesized silica nanoparticles were characterized by FTIR, SEM, TEM, XRD, ICP, etc., and it was found that the particle size was $20 \mathrm{~nm}$ and the purity was about $88 \%$.

To obtain silica from SBA, several steps are needed: washing of the collected SB, shredding it into small pieces, pyrolysis at high temperature, alkali treatment of ash, acidic treatment of the sodium silicate leachate, formation of the silica gel, washing, precipitation, and calcination.

\subsubsection{Coconut Shells}

Coconut (Cocos nucifera) is the major plantation crop of coastal countries such as African countries [151]. A large number of coconuts are produced around the world, and these are mainly used for food and cosmetics. The soft part of the fruit is consumed, while the coir and shell are left behind as waste. Coir is used to make mattresses, while the shell is mainly disposed of into the environment. However, in African countries, coconut waste is conventionally used as a source of fuel and applied in burning processes [152]. Nowadays, with recent research advances, coconut shell waste can be used as a source of activated carbon and/or other value-added minerals. Coconut shell has high silica content and can act as a potential candidate as a source of silica and activated carbon. The use of coconut shell as a source of both silica and activated carbon presents cost-effective green synthesis strategy. Coconut shell can act as another substance for the synthesis of silica from renewable sources. Roughly 33-35\% of a coconut is composed of husk, playing the role of the mesocarp of the fruit. Nowadays, coconut husk is used as a favorable source of fuel for coconut processing and domestic fuel, and as a fiber source for the production of mats, ropes, etc. [153]. The extraction of silica from agricultural wastes involves three sequential steps: acid leaching, mixing alkaline treatment, and precipitation with acid [154]. A schematic diagram is shown in Figure 8. The chemical composition of coconut shell is given below in Table 3. It mainly contains calcium oxide, followed by silica, along with traces of $\mathrm{Al}, \mathrm{K}, \mathrm{Fe}$, and $\mathrm{P}$, in the form of either oxides or chlorides.

\section{Synthesis of Carbon Nanotubes from Coconut Shell Husk Ash}

Carbon nanotubes have gained considerable attention from scientific fields of study such as medicine, drug delivery, photo dynamic therapy, and environmental cleanup. They have numerous advantages over other nanoparticles due to their high mechanical properties, high tensile strength, high electrical conductivity, high aspect ratio, high thermal conductivity, and ultra-light weight. Generally, these nanotubes are synthesized using the physical vapor deposition method or the chemical vapor deposition method; both of these methods are costly and energy intensive. As a result, the synthesis of carbon nanotubes from carbon-rich waste materials like coconut shell husk ash is an economical and environmentally friendly approach. There are several approaches in which coconut shell has been used for the synthesis of carbon nanotubes.

Anuar et al. [153] reported the synthesis of silica nanoparticles from coconut shell ash. In their study, the coconut husks were burned under different temperatures, and were analyzed using XRF to identify their elemental composition. The composition of silica varies from $8-11 \%$ in the husk ash. The husks and silica were characterized by SEM-EDS, XRD for confirmation and to determine the optoelectronic properties of the silica. In another project, Sivasubramanian and Sravanthi (2015) attempted to synthesize silica nanoparticles from coconut shell ash using the $\mathrm{NaOH}$-based alkali treatment method. Ash was treated with $2.5 \mathrm{~N}$ sodium hydroxide to obtain sodium silicate. Finally, silica was formed by treatment with $\mathrm{HCl}$, and was confirmed by SEM-EDS, FTIR, TEM, and XRD [155]. Melati and Hidayati [156] reported the synthesis of multi-walled carbon nanotubes from coconut shell in two steps. First, the coconut shell was activated by treating it at 500-600 ${ }^{\circ} \mathrm{C}$, and it was subsequently converted into carbon nanotubes by applying pyrolysis and a 
wet CVD process. The characterization of the nanotubes revealed the properties of the MWCNTs. It was used for the detection of cancer in mammalian cell lines.

Cleaning and drying of coconut shell waste

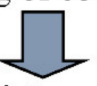

Shredding into small pieces

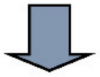

Burning/pyrolysis of the shredded coconut waste (at $700{ }^{\circ} \mathrm{C}$ in a muffle furnace)

Coconut shell ashes

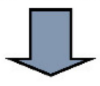

Treatment of ashes with $2.5 \mathrm{NaOH}$ at $90-100{ }^{\circ} \mathrm{C}$ for $4 \mathrm{hrs}$ along with continuous stirring

1 Filtration

Filtrate treated with $5 \mathrm{~N} \mathrm{H}_{2} \mathrm{SO}_{4}$ at $100{ }^{\circ} \mathrm{C}$ along with stirring to obtain silica gel

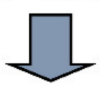

Washing off the solution to remove impurities, heating in an oven at $70{ }^{\circ} \mathrm{C}$ for 15 hrs to form amorphous silica

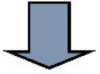

Treatment of amorphous silica with $6 \mathrm{~N} \mathrm{HCl}$ solution for $6 \mathrm{hrs}$ at $90{ }^{\circ} \mathrm{C}$ under reflux system

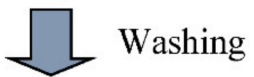

Tratment of solution with $2.5 \mathrm{~N} \mathrm{HCl}$ and $\mathrm{H}_{2} \mathrm{SO}_{4}$ to form white precipitate

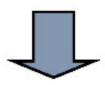

Drying of precipitate in a hot air oven for $30 \mathrm{hrs}$ to get silica nano particles

Figure 8. General method for the synthesis of silica from coconut shell waste.

Table 3. Elemental composition of coconut husk ash (CHA).

\begin{tabular}{cc}
\hline Elements & Composition (\%) \\
\hline $\mathrm{SiO}_{2}$ & $8-12$ \\
$\mathrm{CaO}$ & $27-31.5$ \\
$\mathrm{~K}_{2} \mathrm{O}$ & $17-20$ \\
$\mathrm{Al}_{2} \mathrm{O}_{3}$ & $0.3-0.8$ \\
$\mathrm{SO}_{3}$ & $2-3.5$ \\
$\mathrm{Fe}_{2} \mathrm{O}_{3}$ & $0.3-1.0$ \\
$\mathrm{P}_{2} \mathrm{O}_{5}$ & $0.05-0.3$ \\
$\mathrm{Cl}$ & $35-38$ \\
\hline
\end{tabular}

In the study conducted by Adewumi et al. [157], carbon nanospheres were synthesized from low-cost coconut fibers in three sequential steps: pyrolyzation, physical activation, and ethanol vapor treatment. The analysis of the samples revealed that the spherical-shaped particles had a diameter of 30-150 nm. Hakim et al. [158] applied an easy, environmentally 
friendly approach called the one-step water-assisted (quenching) synthesis method to obtain carbon nanotubes using coconut shell husk ash. The chemical and physical properties of the carbon nanotubes were analyzed using sophisticated instruments, and it was found that the average diameter was $123 \mathrm{~nm}$; the nanotubes were finally applied for the remediation of $\mathrm{Pb}^{2+}$ ions from wastewater. Araga and Sharma [158] synthesized PECV-assisted multiwalled carbon nanotubes (MWCNTs) over coconut shell-derived charcoal pyrolyzed at $900{ }^{\circ} \mathrm{C}$ in a process with only a single step. They used the mineral content in the source material as the catalyst for carbon nanotube (CNT) growth.

Corn Cobs as a Source of Activated Carbon

Maize, or corn (Zea mays), is a popular cereal crop cultivated in many parts of the world [159]. During the processing and production of corn, several waste products are generated, including corn cobs and corn husks [160]. Corn cob waste is a rich source of carbon, and can act as a potential candidate for reparing carbon with ultra-high specific surface area [161]. On the other hand, there are various waste materials that can be applied as activated carbon sources, for instance, date and palm waste, coconut shell waste, corn stalks, and corn cobs. Corn cob is most preferable source of activated carbon, as it is produced in huge amounts around the world. Corn cobs are agricultural waste materials produced in abundance around the world. After extracting the corn, the major fraction of the corn is disposed of as waste, although it is actually a rich source of various minerals. The cob is mainly made up of carbons; therefore, it can be used as a source of biochars or activated carbon.

Activated carbon (AC) refers to carbonaceous materials that possess an internal surface area (that is extremely developed) as well as porosity [162]. The large surface area (an area between $250 \mathrm{~m}^{2} / \mathrm{g}$ and $2000 \mathrm{~m}^{2} / \mathrm{g}$ ) offers a significant ability to adsorb chemicals from liquids/gases, and permit application as a versatile adsorbent under various conditions. AC has been widely used to produce adsorbents, supporting materials, textiles, fabrics, animal foods, etc. [163]. AC is known to be an effective material as a result of its low density, well-developed porosity, accessibility, chemical stability, and low cost [164]. In the last few years, a major emphasis has been placed on the development of AC with ultrahigh specific surface area from both renewable and non-renewable sources using chemical approaches or with the use of chemical vapor deposition (CVD). In the process of water treatment, a substantial amount of $\mathrm{AC}$ is used for the purpose of removing organic and other compounds that could change the water odor and taste [165].

Tsai et al. [166] reported the synthesis of AC from corn cob waste through treatment with different physical and chemical activators such as $\mathrm{NaOH}, \mathrm{KOH}, \mathrm{K}_{2} \mathrm{CO}_{3}$, and $\mathrm{CO}_{2}$. They studied the effect of impregnation time, impregnation ratio, activation temperature, and soaking time on carbon dioxide. The surface area of the AC was analyzed using the BET analyzer. The total pore volume and BET surface area were roughly $1.0 \mathrm{~cm}^{3} / \mathrm{g}$ and $2000 \mathrm{~m}^{2} / \mathrm{g}$, respectively. The findings of this research demonstrate that corn cob activation with $\mathrm{KOH} / \mathrm{K}_{2} \mathrm{CO}_{3}$ and $\mathrm{CO}_{2}$ is able to appropriately prepare large-surface-area ACs. Furthermore, Sai et al. [167] attempted to activate corn cob using potassium salts, and subsequently gasified it with carbon dioxide. The obtained AC had a large surface area, as measured by BET. In the study carried out by Kazmierczak et al. [168], AC was developed from corn cob by activating it using chemical and physical methods. They further studied the sorption properties of the activated carbon. The final product consisted of microporous activated carbon with a high surface area, varying from $\mathrm{m} 337$ to $1213 \mathrm{~m}^{2} / \mathrm{g}$, and showing diverse acid-base characteristics on the surface $[169,170]$. It was also assessed for the adsorption of different materials from the aqueous solutions. Figure 9 shows the schematic diagram for the formation of activated carbon from corn cob. 
Washing of the corn cobs with distilled water<smiles>CC1CCCC1</smiles>

Drying of the corn cob in an oven at $110^{\circ} \mathrm{C}$ till complete dryness<smiles>C1CC2CCC1C2</smiles>

Pyrolysis of the cob at $900{ }^{\circ} \mathrm{C}$

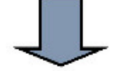

Pyrolysis of char for 60 minutes to ensure pyrolysis has been done completely<smiles>C1CCCC1</smiles>

Cooling down the char

Physical activation of the char samples at $900{ }^{\circ} \mathrm{C}$ using steam as the activation agent

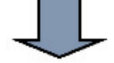

Repetition of the activation steps for at least three times to increase the efficiency of the activated carbon

Figure 9. Schematic diagram for the formation of activated carbon from corn cob.

\section{Domestic Waste}

Domestic waste refers to the materials produced in houses, mainly kitchens. There are several wastes produced in houses that offer potential for the recovery of value-added minerals. Calcium carbonate is a highly important particle that is used in every aspect of our life, as well as in a number of different industries [171]. Calcium carbonates are alkaline earth materials [172] that are present in our environment and which are widely applied in industries like papers [173], paints [174], coating agents, cosmetics [175,176], pharmaceuticals and medicine [177], agriculture, automobiles and textiles [178], and reinforcements, fillers, bio-nanocomposites and bio-ceramics in dentistry [178,179].

Calcium carbonates have excellent properties, including biodegradability, biocompatibility, $\mathrm{pH}$ sensitivity, safety, and cost-effectiveness, and they exhibit polymorphicity [179]. They are very lightweight; thus, they can be used for making lightweight materials. Calcium carbonate exists in three polymorphs in nature, i.e., calcite, aragonite, and vaterite [180]. All these three polymorphs vary with respect to their thermodynamic stability and morphology. Among them, calcite is thermodynamically the most stable, while aragonite shows an intermediate stability, and vaterite $\left(\mu-\mathrm{CaCO}_{3}\right)$ is the least stable polymorph, due to which it is less commonly present in nature. Vaterite can be rapidly transformed into the aragonite and calcite in aqueous solution. It has been experimentally proved that vaterite can transform to aragonite in $60 \mathrm{~min}$ at $60^{\circ} \mathrm{C}$ and to calcite in $24 \mathrm{~h}$ at room temperature [181]. While calcite is rhombohedral in structure, aragonite is spindle- or needle-shaped, while vaterite is octahedral [182]. There are several waste materials that are rich sources of calcium oxide and calcium carbonates, including incense sticks, eggshells, cockle shell waste [183], and gypsum waste; however, the following sections only discuss domestic waste, i.e., incense stick ash and eggshell waste. 


\subsection{Incense Stick Ash (ISA)}

Incense stick ash is one of the most unexplored products, and are generally produced at religious places, i.e., temples, churches, mosques, etc. The burning of incense sticks is a ritual practiced in every religion. However, in South-Asian countries and zones, e.g., China, Taiwan, India, and Japan, large amounts of incense sticks are consumed [184,185]. Incense sticks are cylindrical in shape, and are fragranced and intended to be burned in order to purify the air [186]. After the burning of incense sticks, the ash is left behind in the form of a residue, which is mainly disposed of in rivers and other water bodies, as can be frequently observed in India, where this practice is considered to be holy. Moreover, due to its sacred value in Hinduism, incense is even applied on the forehead or eaten as Prasad. These incense sticks mainly contain calcium oxide, silica, ferrous, alumina, rutile, $\mathrm{Mg}$, and traces of oxides of $\mathrm{K}, \mathrm{Na}$, and $\mathrm{Mn}$. The sticks contain $45-60 \%$ calcium oxides or carbonates, $10-20 \%$ silica, and $5-7 \% \mathrm{Mg}$, with less than $5 \%$ consisting of other materials. The disposal of incense stick ash into water pollutes it by increasing the concentration of $\mathrm{Ca}$ and $\mathrm{Mg}$, ultimately increasing the water hardness. These two elements also play a role in increasing the $\mathrm{pH}$ of water by forming precipitates of hydroxides in it. Due to the high calcium content, incense stick ash can act as a potential source material for the recovery of calcium oxides and carbonates. The complete schematic diagram for the synthesis of calcium carbonate from incense stick ash is given below in Figure 10.

\subsection{Eggshell Waste}

Eggshells are another waste product produced by houses and industry, and are still classified as a byproduct of the poultry industry. Approximately one million tons of eggshell are generated per year globally. Currently, eggshell waste is dumped into landfills. Such practices may lead to the deterioration of agricultural land [187]. This waste is mainly made up of calcium oxides that are meant to provide safety to growing chicks. Due to their high calcium content (composition shown in Table 4), eggshells can be used as a potential alternative source of calcium oxide or carbonates [188,189].

The recovery of calcium oxides and carbonates from incense stick ash and poultry is easy, economical, and environmental friendly. Recovery from such wastes focuses on the use of renewable sources without affecting our natural resources. Consequently, it also minimizes pollution in the form of solid waste. Hassan et al. $[190,191]$ reported the synthesis of $\mathrm{CaCO}_{3} \mathrm{NPs}$ from chicken eggshell waste, which involved the following steps: cleaning and size reduction of eggshells, followed by surface modification using the sonochemical method to achieve enhanced dispersion $[190,191]$. In another study, Hariharan et al. [192] attempted to perform the synthesis of calcite nanoparticles from eggshell waste using gelatin. Chicken eggshells were used to obtain the calcite polymorph of calcium carbonate using gelatin by means of the precipitation method. Nanocalcite was confirmed using FTIR, XRD, UV-Visible spectroscopy, and SEM. The particles were identified as calcite polymorphs with a particle size of $25 \mathrm{~nm}$. The results obtained in the FTIR experiments confirmed the creation of calcite, with characteristic absorption bands being observed at 712,876 , and $1410 \mathrm{~cm}^{-1}$, corresponding to the bending and stretching vibrations of $\mathrm{CO}_{3}{ }^{2-}$ ions. A comparison was also made between the obtained results and calcium carbonate synthesized with no gelatin.

Calcium oxides are currently produced at commercial levels from calcium-based precursor materials like calcium nitrate [193], calcium hydroxide [194], calcium sulphate, and calcium chloride [193] using techniques such as thermal decomposition [194], microwave irradiation [195], sol-gel [196], co-precipitation [197,198], hydrogen plasma-metal reaction [199], and sonochemical synthesis [191,200]. However, the use of the abovementioned calcium precursors for the synthesis of calcium oxide nanoparticles using the techniques described above makes the whole process costly and energy intensive, and also requires the use of hazardous chemicals. As a result, for the synthesis of calcium oxide nanoparticles, there is a need to switch to green methods. Some of the most common calcium-rich waste materials are cockle shells [201], eggshells [202], gypsum waste, and 
incense stick ash. Among these, incense stick ash is the most underestimated calcium-rich waste material, and is produced abundantly at religious places and in houses. Such materials can act as potential substitutes for various calcium precursors used at commercial level $[203,204]$.

Incense stick ash

$$
\downarrow \text { Water, slurry }
$$

Magnetic separation of ferrous

$$
\downarrow \rightleftarrows \text { Ferrous, Drying at } 40-45^{\circ} \mathrm{C}
$$

$2 \mathrm{~N} \mathrm{H}_{2} \mathrm{SO}_{4}$ Treatment $\left(80-100{ }^{\circ} \mathrm{C}\right)$

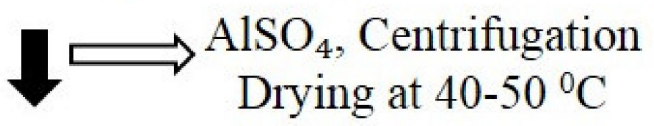

$4 \mathrm{M} \mathrm{NaOH}$ Treatment, $\left(90-95{ }^{\circ} \mathrm{C}\right)$

$$
\neg \underset{\text { Centrifugation, Washing }}{\longrightarrow \text { Silica, } \mathrm{Na}_{2} \mathrm{SiO}_{3}}
$$

Calcination of residue at $450{ }^{\circ} \mathrm{C}$ for 3 hours

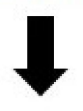

$4 \mathrm{M} \mathrm{HCl}$ treatment at $40-45^{\circ} \mathrm{C}$ for 2 hours

$$
\checkmark \text { Centrifugation, Residue }
$$

$$
\text { Leachate }+ \text { Methanol, stirring }
$$

$\checkmark$ Centrifugation, precipitate

$$
\begin{aligned}
& \text { Supernatant }+\mathrm{Na}_{2} \mathrm{CO}_{3} \text {, stirring } \\
& \text { Precipitate } \\
& \text { Powdered } \mathrm{CaCO}_{3}
\end{aligned}
$$

Figure 10. Flow chart for the synthesis of $\mathrm{CaCO}_{3}$ from incense stick ash, adopted from Yadav et al., open access journal Applied Sciences, 2021 [129]. 
Table 4. The chemical composition of chicken eggshells.

\begin{tabular}{cc}
\hline Chemical Elements & Concentration $(\mathrm{mg} / \mathrm{L})$ \\
\hline $\mathrm{Ca}$ & $2296-2304$ \\
$\mathrm{Mg}$ & $849-852$ \\
$\mathrm{Na}$ & $33-35$ \\
$\mathrm{~K}$ & $16-19$ \\
$\mathrm{Fe}$ & $1.01-1.43$ \\
$\mathrm{Zn}$ & $0.95-1.03$ \\
$\mathrm{Cu}$ & $0.062-0.064$ \\
\hline
\end{tabular}

Tangboriboon et al. [205] synthesized calcium oxide nanoparticles from duck eggshell waste using the calcination technique and analyzed their properties. The duck eggshells and the calcined eggshells were analyzed using FTIR, STA, XRD, XRF, TEM, BET, a particle size analyzer, and an impedance analyzer. The microscopy revealed the good dispersion quality of the calcium oxide nanoparticles, which had a spherical shape, with a ceramic yield of 53\%. In another study, Jirimali et al. [206] reported the synthesis of calcium oxide and hydroxyapaptite using eggshell for the development of LLDPE Polymer Nanocomposite [206]. Mohadi et al. [202] synthesized the calcium oxide nanoparticles from the chicken eggshell waste by calcination of the shells at different temperatures ranging from 600 to $1000{ }^{\circ} \mathrm{C}$. The synthesized calcium oxide nanoparticles were analyzed using FTIR, SEM-EDS, XRD, and BET. The calcium oxides were porous in nature, with pore sizes of $6.6 \mathrm{~nm}$, meaning they could be classified as mesoporous, and with a surface area of $68 \mathrm{~m}^{2} / \mathrm{g}$ [202].

A typical TEM image of calcium oxide nanoparticles obtained from eggshell waste is shown in Figure 11 [204].

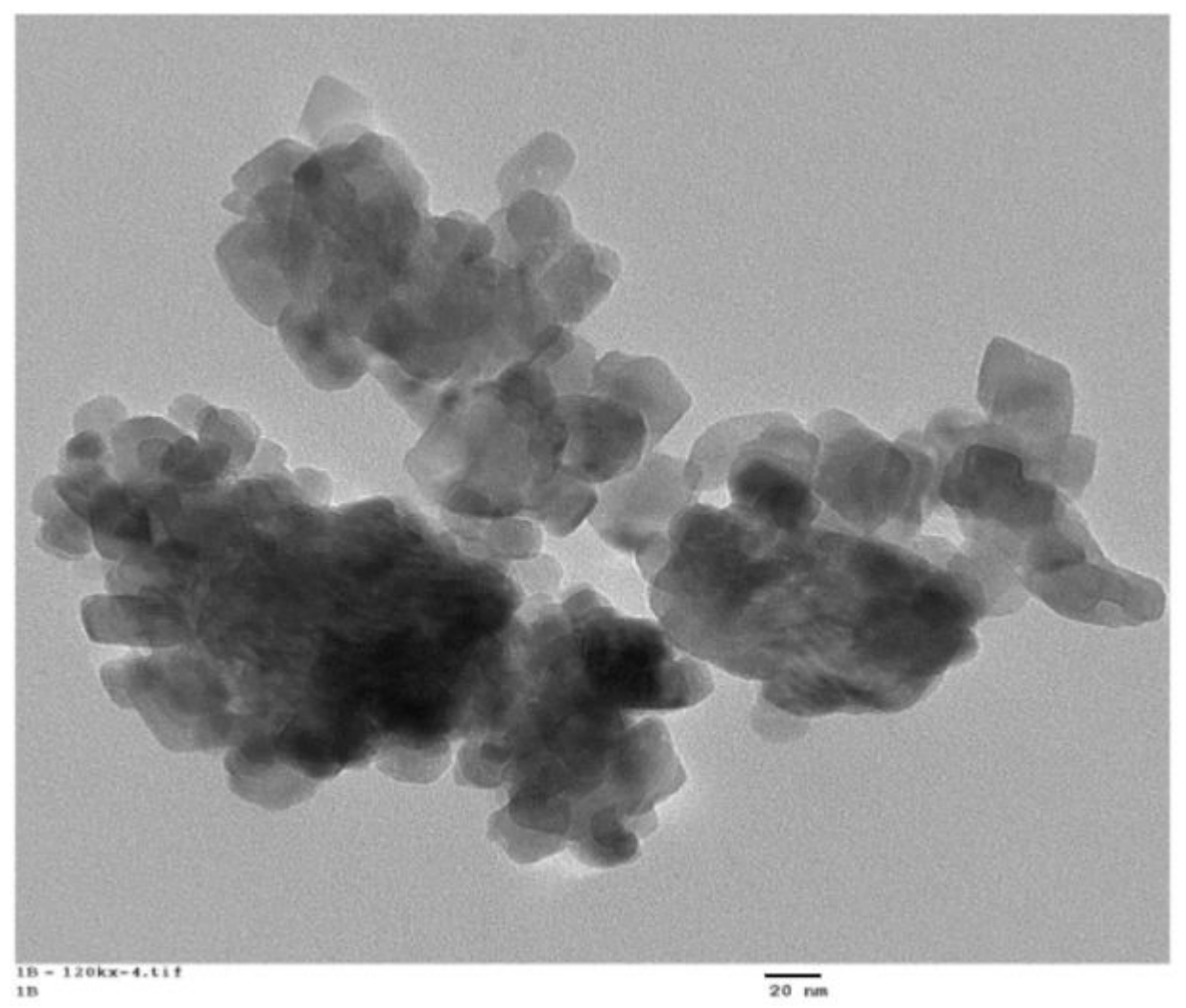

Figure 11. TEM image of calcium oxide nanoparticles obtained from eggshell waste adapted from (Render et al. [204]). 
There are several reports of the synthesis of composite materials and fertilizers from plastic waste; however, research conducted in this field is very limited. A lot of work needs to be performed in this field in future, since plastics constitute a major global problem.

\section{Conclusions}

Waste management mainly addresses two subjects: resource recovery and final disposal. Individuals worldwide earn revenue from each stage, through the recovery of reusable materials and, to a lesser extent, the conversion of waste to energy. Turning waste into wealth not only makes sensible environmental sense, but also turns "trash" into "cash". Agricultural waste materials are mainly organic in nature; they are biodegradable, and can be used for the development of carbon-based materials and activated carbon. The burning of agricultural waste leads to the pollution of the air. In recent decades, waste management and technology awareness programs have successfully transformed hazardous materials (e.g., CFA and red mud) into useable value-added minerals. Both of these materials have been applied in the fields of ceramics, construction materials, and metallurgy, and have proved to be highly valuable. Poultry waste and domestic waste have been also been found to be important precursors of carbon and calcium oxides. The ash from incense sticks is among the emerging domestic byproducts produced at religious places, and have proved to be a valuable source of calcium oxide. All of these waste byproducts have gained importance with the advent and increasing significance of renewable energy sources. The recovery of minerals from such wastes is an economical and environmentally friendly method. Such materials act as alternative precursors, reducing the burden on industry. The use of such wastes reduces pollution at minimum cost, while developing materials and generating revenue.

Author Contributions: Conceptualization, G.G., S.M. and N.G.; Data curation, N.C., G.G., S.I. and S.M.; methodology, N.C., N.G. and V.T.; validation, K.K.Y., S.I., B.-H.J. and S.M.; formal analysis, V.K.Y., N.G. and A.A.; resources, K.K.Y., B.-H.J. and A.A.; writing - original draft preparation, V.K.Y., N.C. and K.K.Y.; writing-review and editing, V.K.Y., V.T., G.G., S.M. and A.A.; supervision, V.K.Y., S.I. and B.-H.J.; project administration V.K.Y., N.C., K.K.Y. and A.A.; Funding acquisition, B.-H.J., S.I., V.T. and A.A.; Investigation, V.K.Y. and V.T.; Software's, G.G., N.G. and B.-H.J.; Visualization, K.K.Y. and B.-H.J. All authors have read and agreed to the published version of the manuscript.

Funding: The authors gratefully acknowledge the Deanship of Scientific Research, King Khalid University (KKU), Abha-Asir, Kingdom of Saudi Arabia for funding this research work under the grant number RGP.2/58/42. This study was supported by the Korea Environment Industry \& Technology Institute (KEITI) through Subsurface Environment Management (SEM) Projects, funded by Korea Ministry of Environment (MOE)(No.2020002480007).

Institutional Review Board Statement: Not applicable.

Informed Consent Statement: Not applicable.

Data Availability Statement: Not applicable.

Acknowledgments: The authors gratefully acknowledge the Deanship of Scientific Research, King Khalid University (KKU), Abha-Asir, Kingdom of Saudi Arabia for funding this research work under the grant number RGP.2/58/42. This study was supported by the Korea Environment Industry \& Technology Institute (KEITI) through Subsurface Environment Management (SEM) Projects, funded by Korea Ministry of Environment (MOE)(No.2020002480007).

Conflicts of Interest: The authors declare no conflict of interest.

\section{References}

1. Lin, T.C.; Krishnaswamy, G.; Chi, D.S. Incense smoke: Clinical, structural and molecular effects on airway disease. Clin. Mol. Allergy 2008, 6, 3. [CrossRef]

2. Khan, T.; Mubeen, U. Wheat Straw: A pragmatic overview. Curr. Res. J. Biol. Sci. 2012, 4, 673-675.

3. Schnitzer, M.; Monreal, C.; Powell, E. Wheat straw biomass: A resource for high-value chemicals. J. Environ. Sci. Health 2014, 49, 51-67. [CrossRef] 
4. Zhang, Z.; Li, C.; Davies, E.G.; Liu, Y. Agricultural Waste. Water Environ. Res. 2013, 85, 1377-1451. [CrossRef]

5. Domínguez-Escribá, L.; Porcar, M. Rice straw management: The big waste. Biofuels Bioprod. Biorefining 2010, 4, 154-159. [CrossRef]

6. Hasnain, M.H.; Javed, U.; Ali, A.; Zafar, M.S. Eco-friendly utilization of rice husk ash and bagasse ash blend as partial sand replacement in self-compacting concrete. Constr. Build. Mater. 2021, 273, 121753. [CrossRef]

7. Ganiron, T.U., Jr. Sustainable Management of Waste Coconut Shells as Aggregates in Concrete Mixture. J. Eng. Sci. Technol. Rev. 2013, 6, 7-14. [CrossRef]

8. Ahmad, T.; Danish, M.; Rafatullah, M.; Ghazali, A.; Sulaiman, O.; Hashim, R.; Ibrahim, M.N.M. The use of date palm as a potential adsorbent for wastewater treatment: A review. Environ. Sci. Pollut. Res. 2012, 19, 1464-1484. [CrossRef]

9. Gómez, B.; Gullón, B.; Yáñez, R.; Parajó, J.C.; Alonso, J.L. Pectic Oligosacharides from Lemon Peel Wastes: Production, Purification, and Chemical Characterization. J. Agric. Food Chem. 2013, 61, 10043-10053. [CrossRef]

10. Landge, A.; VShahade, I.; Topare, N. Application of Biosorbent Prunus Amygdalus (Almond) Nut Shell Carbon on Treatment of Cr (VI) Contaminated Waste Water. In Proceedings of the 66th Annual Session of Indian Institute of Chemical Engineers, Pune, Indian, 27-30 December 2013; pp. 1-5.

11. Zhang, Z.; Gonzalez, A.M.; Davies, E.; Liu, Y. Agricultural Wastes. Water Environ. Res. 2012, 84, 1386-1406. [CrossRef]

12. Mohomane, S.; Linganiso, L.Z.; Linganiso, E.C.; Motaung, T.E.; Songca, S.P. The application of fly ash as industrial waste material in building construction industries. In "Waste-To-Profit"(W-T-P); Nova Science Publishers Inc.: New York, NY, USA, 2018; pp. 181-202.

13. Nordin, N.; Abdullah, M.M.A.B.; Tahir, M.F.M.; Sandu, A.V.; Hussin, K. Utilization of fly ash waste as construction material. Int. J. Conserv. Sci. 2016, 7, 161-166.

14. Rai, S.; Wasewar, K.L.; Lataye, D.H.; Mishra, R.S.; Puttewar, S.; Chaddha, M.J.; Mahindiran, P.; Mukhopadhyay, J. Neutralization of red mud with pickling waste liquor using Taguchi's design of experimental methodology. Waste Manag. Res. 2012, 30, 922-930. [CrossRef] [PubMed]

15. Wang, P.; Liu, D.Y. Physical and Chemical Properties of Sintering Red Mud and Bayer Red Mud and the Implications for Beneficial Utilization. Materials 2012, 5, 1800-1810. [CrossRef]

16. Geraldo, R.H.; Pinheiro, S.M.; Silva, J.S.; Andrade, H.M.; Dweck, J.; Gonçalves, J.; Camarini, G. Gypsum plaster waste recycling: A potential environmental and industrial solution. J. Clean. Prod. 2017, 164, 288-300. [CrossRef]

17. Romero-Hermida, I.; Morales-Flórez, V.; Santos, A.; Villena, A.; Esquivias, L. Technological Proposals for Recycling Industrial Wastes for Environmental Applications. Minerals 2014, 4, 746-757. [CrossRef]

18. Ahmadi, M.; Bayati, N.; Babaei, A.; Teymouri, P. Sludge characterization of an industrial wastewater treatmnt plant, Iran. Iran. J. Health Sci. 2013, 1, 10-18.

19. Shreekant, R.; Vardhan, A.M.H. Utilization of Iron Ore Waste in Brick Making For the Construction Industry. Int. J. Earth Sci. Eng. 2016, 9, 450-455.

20. Awuchi, C.G.; Igwe, S.V. Industrial waste management: Brief survey and advice to cottage, small, and medium scale industries in Uganda. Int. J. Adv. Acad. Res. 2017, 3, 26-43.

21. Fecheyr-Lippens, D.; Nallapaneni, A.; Shawkey, M. Exploring the Use of Unprocessed Waste Chicken Eggshells for UV-Protective Applications. Sustainability 2017, 9, 232. [CrossRef]

22. Meng, X.; Deng, D. Trash to Treasure: Waste Eggshells Used as Reactor and Template for Synthesis of Cog $\mathrm{S}_{8} \mathrm{Nanorod}^{\mathrm{A}} \mathrm{Arays}$ on Carbon Fibers for Energy Storage. Chem. Mater. 2016, 28, 3897-3904. [CrossRef]

23. Ummartyotin, S.; Manuspiya, H. A critical review of eggshell waste: An effective source of hydroxyapatite as photocatalyst. J. Met. Mater. Miner. 2018, 28, 124-135.

24. Adeoye, A.; Man, H.C.; Soom, M.; Thamer, A.M.; Oluwakunmi, A.C. Poultry waste generation, management and the environment: A case of Minna, North Central Nigeria. J. Solid Waste Technol. Manag. 2015, 41, 146-156. [CrossRef]

25. Bolan, N.S.; Szogi, A.A.; Chuasavathi, T.; Seshadri, B.; Rothrock, M.J.; Panneerselvam, P. Uses and management of poultry litter. World's Poult. Sci. J. 2010, 66, 673-698. [CrossRef]

26. Abdel-Shafy, H.I.; Mohamed-Mansour, M.S. Solid waste issue: Sources, composition, disposal, recycling and valorization. Egypt. J. Pet. 2018, 27, 1275-1290. [CrossRef]

27. Latake, T.; Kulkarni, A.; Bhosale, S. Disposal of Solid Waste For Landfilling In Karad City A Review. In International Journal for Research in Applied Science and Engineering Technology; Seventh Sense Research Group: Thanjavur, India, 2016; p. 4. ISSN $2395-0072$.

28. Ali, S.M.; Pervaiz, A.; Afzal, B.; Hamid, N.; Yasmin, A. Open dumping of municipal solid waste and its hazardous impacts on soil and vegetation diversity at waste dumping sites of Islamabad city. J. King Saudi Univ. Sci. 2014, 26, 59-65. [CrossRef]

29. Sakawi, Z.; Mastura, S.; Jaafar, O.; Mahmud, M. Community perception of odour pollution from landfills. Res. J. Environ. Earth Sci. 2017, 3, 142-145.

30. De Moraes, C.M.; Stanczyk, N.M.; Betz, H.S.; Pulido, H.; Sim, D.G.; Read, A.F.; Mescher, M.C. Malaria-induced changes in host odors enhance mosquito attraction. Proc. Natl. Acad. Sci. USA 2014, 111, 11079-11084. [CrossRef]

31. Sijakova Ivanova, T.; Panov, Z.; Blazev, K.; Zajkova, V. Investigation of fly ash heavy metals content and physico chemical properties from thermal power plant, Republic of Macedonia. Int. J. Eng. Sci. Technol. (IJEST) 2011, 3, 8219-8225.

32. Ozden, B.; Brennan, C.; Landsberger, S. Investigation of bauxite residue (red mud) in terms of its environmental risk. J. Radioanal. Nucl. Chem. 2019, 319, 339-346. [CrossRef] 
33. Nguyen, H.T.; Bui, T.H.; Pham, V.T.H.Q.; Do, M.Q.; Hoang, M.D.; Le, V.Q. Leaching Behavior and Immobilization of Heavy Metals in Geopolymer Synthesized from Red Mud and Fly Ash. In Key Engineering Materials; Trans Tech Publications Ltd.: Zurich, Switzerland, 2018; pp. 518-522.

34. Vongdala, N.; Tran, H.D.; Xuan, T.D.; Teschke, R.; Khanh, T.D. Heavy Metal Accumulation in Water, Soil, and Plants of Municipal Solid Waste Landfill in Vientiane, Laos. Int. J. Environ. Res. Public Health 2019, 16, 22. [CrossRef] [PubMed]

35. Lokeshwari, M.; Swamy, C.N. Waste to wealth-Agriculture solid waste management study. Poll. Res. $2010,29,513-517$.

36. Jain, A.K.; Gupta, V.K.; Bhatnagar, A.; Bhatnagar, A. Utilisation of Industrial Waste Products as Adsorbents for the Removal of Dyes. J. Hazard. Mater. 2003, 101, 31-42. [CrossRef]

37. Sulyman, M.; Namiesnik, J.; Gierak, A. Low-cost Adsorbents Derived from Agricultural By-products/Wastes for Enhancing Contaminant Uptakes from Wastewater: A Review. Pol. J. Environ. Stud. 2017, 26, 479-510. [CrossRef]

38. Krishnappa, V. Properties and Application of Geopolymer Masonry Units. In International Journal of Civil Engineering EFES; Seventh Sense Research Group: Thanjavur, India, 2015; pp. 117-119. ISSN 2348-8352.

39. Mohajerani, A.; Suter, D.; Jeffrey-Bailey, T.; Song, T.; Arulrajah, A.; Horpibulsuk, S.; Law, D. Recycling waste materials in geopolymer concrete. Clean Technol. Environ. Policy 2019, 21, 493-515. [CrossRef]

40. Bernardo, E.; Dattoli, A.; Bonomo, E.; Esposito, L.; Rambaldi, E.; Tucci, A. Application of an Industrial Waste Glass in “GlassCeramic Stoneware". Int. J. Appl. Ceram. Technol. 2011, 8, 1153-1162. [CrossRef]

41. Skenderovic, I.; Kalac, B.; Becirovic, S. Environmental pollution and waste management. Balk. J. Health Sci. $2015,3,2-10$.

42. Kowalski, Z.; Krupa-Żuczek, K. A model of the meat waste management. Pol. J. Chem. Technol. 2007, 9, 91-97. [CrossRef]

43. Mladenov, M.; Pelovski, Y. Utilization of wastes from pulp and paper industry. J. Univ. Chem. Technol. Metall. 2010, 45, 33-38.

44. Simão, L.; Hotza, D.; Raupp-Pereira, F.; Labrincha, J.A.; Montedo, O. Wastes from pulp and paper mills-A review of generation and recycling alternatives. Cerâmica 2018, 64, 443-453. [CrossRef]

45. Fela, K.; Wieczorek-Ciurowa, K.; Konopka, M.; Woźny, Z. Present and prospective leather industry waste disposal. Pol. J. Chem. Technol. 2011, 13, 53-55. [CrossRef]

46. Paramanandham, J.; Ronald Ross, P. Lignin and cellulose content in coir waste on subject to sequential washing. J. Chem. Chem. Res. Vol. 2011, 1, 10-13.

47. Noguera, P.; Abad, M.; Noguera, V.; Puchades, R.; Maquieira, A. Coconut coir waste, a new and viable ecologically- Friendly peat substitute. In XXV International Horticultural Congress, Part 7: Quality of Horticultural Products 517; International Society for Horticultural Science: Brussels, Belgium, 1998; pp. 279-286.

48. Baz, W.A.; Nawar, L.S.; Aly, M.M. Production of biofuel from sugarcane baggase wastes using Saccharomyces cerevisiae. J. Exp. Biol. 2017, 5, 6.

49. Mzimela, Z.; Mochane, M.; Tshwafo, M. Sugarcane bagasse waste management. In "Waste-to-Profit"? (W-t-P): Value Added Products to Generate Wealth for a Sustainable Economy; Nova Science Publishers: Hauppauge, NY, USA, 2018; Volume 1, pp. $293-302$.

50. Xu, G.; Shi, X. Characteristics and applications of fly ash as a sustainable construction material: A state-of-the-art review. Resour. Conserv. Recycl. 2018, 136, 95-109. [CrossRef]

51. Lieberman, R.N.; Knop, Y.; Izquierdo, M.; Palmerola, N.M.; de la Rosa, J.; Cohen, H.; Querol, X. Potential of hazardous waste encapsulation in concrete with coal fly ash and bivalve shells. J. Clean. Prod. 2018, 185, 870-881. [CrossRef]

52. Sahu, G.; Bag, A.; Chatterjee, N.; Mukherjee, A. Potential use of flyash in agriculture: A way to improve soil health. J. Pharmacogn. Phytochem. 2017, 6, 873-880.

53. Sheoran, H.S.; Duhan, B.S.; Kumar, A. Effect of Fly Ash Application on Soil Properties: A Review. J. Agroecol. Nat. Resour. Manag. 2014, 1, 98-103.

54. Kalra, N.; Jain, M.C.; Joshi, H.C.; Choudhary, R.; Harit, R.C.; Vatsa, B.K.; Sharma, S.K.; Kumar, V. Flyash as a soil conditioner and fertilizer. Bioresour. Technol. 1998, 64, 163-167. [CrossRef]

55. Yadav, V.K.; Fulekar, M.H. Advances in Methods for Recovery of Ferrous, Alumina, and Silica Nanoparticles from Fly Ash Waste. Ceramics 2020, 3, 34. [CrossRef]

56. Yadav, V.K.; Pandita, R. Fly Ash Properties and Their Applications as a Soil Ameliorant. In Amelioration Technology for Soil Sustainability; IGI Global: Hershey, PA, USA, 2019; pp. 59-89.

57. Ahmaruzzaman, M. Role of fly ash in the removal of organic pollutants from wastewater. Energy Fuels 2019, $23,1494-1511$. [CrossRef]

58. Singh, V.K.; Singh, R.S.; Tiwari, N.; Singh, J.K.; Gode, F.; Sharma, Y.C. Removal of malathion from aqueous solutions and waste water using fly ash. J. Water Resour. Prot. 2010, 2, 322. [CrossRef]

59. Al-Harahsheh, M.S.; Alzboon, K.; Al-Makhadmeh, L.; Hararah, M.; Mahasneh, M. Fly ash based geopolymer for heavy metal removal: A case study on copper removal. J. Environ. Chem. Eng. 2011, 3, 1669-1677. [CrossRef]

60. Ge, C.J.; Yoon, K.S.; Choi, J.N. Application of Fly Ash as an Adsorbent for Removal of Air and Water Pollutants. Appl. Sci. 2018, 8, 1116. [CrossRef]

61. Yeole, K.; Kadam, P.; Mhaske, S. Synthesis and characterization of fly ash-zinc oxide nanocomposite. J. Mater. Res. Technol. 2014, 3, 186-190. [CrossRef]

62. Yao, Z.T.; Ji, X.S.; Sarker, K.; Tang, J.H.; Ge, L.Q.; Xia, M.S.; Xi, Y.Q. A comprehensive review on the applications of coal fly ash. Earth-Sci. Rev. 2015, 141, 105-121. [CrossRef] 
63. Yu, J.; Li, X.; Fleming, D.; Meng, Z.; Wang, D.; Tahmasebi, A. Analysis on Characteristics of Fly Ash from Coal Fired Power Stations. Energy Procedia 2012, 17, 3-9. [CrossRef]

64. Abbas, S.; Saleem, M.A.; Kazmi, S.M.S.; Munir, M.J. Production of sustainable clay bricks using waste fly ash: Mechanical and durability properties. J. Build. Eng. 2017, 14, 7-14. [CrossRef]

65. Pawlik, T.; Michalik, D.; Sopicka-Lizer, M.; Godzierz, M. Manufacturing of Light Weight Aggregates from the Local Waste Materials for Application in the Building Concrete. In Materials Science Forum; Trans Tech Publications Ltd: Bäch, Switzerland, 2017; Volume 904, pp. 174-178. [CrossRef]

66. Bouzoubaâ, N.; Zhang, M.H.; Zakaria, M.; Malhotra, V.M.; Golden, D.M. Blended fly ash cements-A review. ACI Mater. J. 1999, 96, 641-650.

67. Nataatmadja, A.; Haigh, R.; Amaratunga, D. (Eds.) Development of low-cost fly ash bricks. In Proceedings of the CIB International Conference on Building Education and Research, Heritance Kandalama, Sri Lanka, 11-15 February 2008; pp. 831-843.

68. Bohara, N. Study of the Influence of Fly Ash and Its Content in Marshall Properties of Asphalt Concrete. J. Sustain. Constr. Mater. Technol. 2018, 3, 261-270. [CrossRef]

69. Mishra, M.K.; Karanam, U. Geotechnical characterization of fly ash composites for backfilling mine voids. Geotech. Geol. Eng. 2006, 24, 1749-1765. [CrossRef]

70. Yadav, V.K.; Fulekar, M.H. Isolation and charcterization of iron nanoparticles from coal fly ash from Gandhinagar Gujarat thermal power plant a mechanical-method-of-isolation. Int. J. Eng. Res. Technol. 2014, 3, 471-477.

71. Kumar, S.; Das, S.K.; Daspoddar, K. Synthesis of mullite aggregates from fly ash: Effect on thermomechanical behaviour of low cement castables. Br. Ceram. Trans. 2004, 103, 176-180. [CrossRef]

72. Yan, F.; Jiang, J.; Li, K.; Liu, N.; Chen, X.; Gao, Y.; Tian, S. Green Synthesis of Nanosilica from Coal Fly Ash and Its Stabilizing Effect on $\mathrm{CaO}$ Sorbents for $\mathrm{CO}_{2}$ Capture. Environ. Sci. Technol. 2017, 51, 7606-7615. [CrossRef] [PubMed]

73. Ojha, K.; Pradhan, N.C.; Samanta, A.N. Zeolite from fly ash: Synthesis and characterization. Bull. Mater. Sci. 2004, $27,555-564$. [CrossRef]

74. Kumar, S.; Srivastava, V.; Agarwal, V.C. Utilization of fly ash and lime in PPC concrete. Int. J. Eng. Tech. Res. (IJETR) 2015, 3, 121-124.

75. Al-Shether, B.; Shamsa, M.; Al-Attar, T. Relationship between amorphous silica in source materials and compressive strength of geopolymer concrete. In MATEC Web of Conferences; EDP Sciences: Bhagdad, Iraq, 2018; Volume 162, p. 02019.

76. Havlíček, D.; Přibil, R.; Kratochvíl, B. Content of quartz and mullite in some selected power-plant fly ash in Czechoslovakia. Atmos. Environ. 1989, 23, 701-706. [CrossRef]

77. Ryu, G.; Lee, Y.B.; Koh, K.T.; Chung, Y.S. The mechanical properties of fly ash-based geopolymer concrete with alkaline activators. Constr. Build. Mater. 2013, 47, 409-418. [CrossRef]

78. Fuller, A.; Maier, J.; Karampinis, E.; Kalivodova, J.; Grammelis, P.; Kakaras, E.; Scheffknecht, G. Fly Ash Formation and Characteristics from (co-)Combustion of an Herbaceous Biomass and a Greek Lignite (Low-Rank Coal) in a Pulverized Fuel Pilot-Scale Test Facility. Energies 2018, 11, 1581. [CrossRef]

79. Inada, M.; Eguchi, Y.; Enomoto, N.; Hojo, J. Synthesis of zeolite from coal fly ashes with different silica-alumina composition. Fuel 2015, 84, 299-304. [CrossRef]

80. Yadav, V.K.; Suriyaprabha, R.; Khan, S.H.; Singh, B.; Gnanamoorthy, G.; Choudhary, N.; Kalasariya, H. A novel and efficient method for the synthesis of amorphous nanosilica from fly ash tiles. Mater. Today Proc. 2020, 26, 701-705. [CrossRef]

81. Colilla, M.; Baeza, A.; Vallet-Regí, M. Mesoporous Silica Nanoparticles for Drug Delivery and Controlled Release Applications. Sol-Gel Handb. 2015, 1309-1344. [CrossRef]

82. Devi, L.R.; Singh, M.O. Application of silica based heterogeneous catalyst for the synthesis of bioactive heterocycles. In Heterogeneous Catalysis; Penoni, A., Penoni, A., Eds.; CRC Press: Boca Raton, FL, USA, 2014; Chapter 6; pp. 163-190.

83. Sharma, P.; Han, M.H.; Cho, C.H. Synthesis of Zeolite Nanomolecular Sieves of Different Si/Al Ratios. J. Nanomater. 2015, 16, 9. [CrossRef]

84. Singh, G.B.; Subramaniam, K. Characterization of Indian fly ashes using different Experimental Techniques. Indian Concr. J. 2018, $92,10-23$.

85. Zhao, L.; Xiao, H.; Wang, B.; Sun, Q. Characterization of Glasses in One Type of Alumina Rich Fly Ash by Chemical Digestion Methods: Implications for Alumina Extraction. J. Chem. 2016, 2016, 10. [CrossRef]

86. Ribeiro, M.J.; Abrantes, J.C.; Ferreira, J.M.; Labrincha, J.A. Recycling of Alrich industrial sludge in refractory ceramic pressed bodies. Ceram. Int. 2002, 28, 319-326. [CrossRef]

87. Paglia, G.; Buckley, C.E.; Rohl, A.L.; Hart, R.D.; Winter, K.; Studer, A.J.; Hunter, B.A.; Hanna, J.V. Boehmite derived $\gamma$-alumina system. 1. Structural evolution with temperature, with the identification and structural determination of a new transition phase, $\gamma$ '-alumina. Chem. Mater. 2004, 16, 220-236.

88. Piconi, C. Alumina Ceramics for Biomedical Applications. In Proceedings of the 3rd International Conference on "High-Tech Aluminas and Unfolding their Business Prospects" (Aluminas-2013), Kolkata, West Bengal, India, 20 March 2013.

89. Fomenko, E.; Anshits, N.; Solovyov, A.L.; Mikhaylova, O.A.; Anshits, A.G. Composition and Morphology Of Fly Ash Cenospheres Produced from the Combustion of Kuznetsk Coal. Energy Fuels 2013, 27, 5440-5448. [CrossRef] 
90. Fomenko, E.V.; Anshits, N.N.; Vasil'Eva, N.G.; Rogovenko, E.S.; Mikhaylova, O.A.; Mazurova, E.V.; Solovyev, L.A.; Anshits, A.G. Composition and structure of the shells of aluminosilicate microspheres in fly ash formed on the combustion of Ekibastuz coal. Solid Fuel Chem. 2016, 50, 238-247. [CrossRef]

91. Kruger, R.A. The Use of Cenospheres in Refractories. Energeia 1996, 7, 1-5.

92. Ghosal, S.; Ebert, J.L.; Self, S.A. Chemical composition and size distributions for fly ashes. Fuel Process. Technol. 1995, 44, 81-94. [CrossRef]

93. Alcala, J.C.; Davila, R.M.; Quintero, R.L. Recovery of cenospheres and magnetite from coal burning power plant fly ash. Trans. Iron Steel Inst. Jpn. 1987, 27, 531-538. [CrossRef]

94. Yadav, V.K.; Yadav, K.K.; Tirth, V.; Jangid, A.; Gnanamoorthy, G.; Choudhary, N.; Islam, S.; Gupta, N.; Son, C.T.; Jeon, B.-H. Recent Advances in Methods for Recovery of Cenospheres from Fly Ash and Their Emerging Applications in Ceramics, Composites, Polymers and Environmental Cleanup. Crystals 2021, 11, 1067. [CrossRef]

95. Rodrigo, D.D.; Boch, P. High purity mullite ceramics by reaction sintering. Int. J. High Technol. Ceram. 1985, 1, 3-30. [CrossRef]

96. Schneider, H.; Fischer, R.X.; Schreuer, J. Mullite: Crystal Structure and Related Properties. J. Am. Ceram. Soc. 2015, 98, 2948-2967. [CrossRef]

97. Schmucker, M.; Hildmann, B.; Schneider, H. Mechanism of 2/1-to 3/2-mullite transformation at 1650 C. Am. Mineral. 2002, 87, 1190-1193. [CrossRef]

98. Jiangfeng, C.H.E.N.; Longyi, S.H.A.O.; Jing, L.U. Synthesis of Mullite from High-alumina Fly Ash: A Case from the Jungar Power Plant in Inner Mongolia, Northern China. Acta Geol. Sin. Engl. Ed. 2008, 82, 99-104. [CrossRef]

99. Yadav, V.K.; Saxena, P.; Lal, C.; Gnanamoorthy, G.; Choudhary, N.; Singh, B.; Tavker, N.; Kalasariya, H.; Kumar, P. Synthesis and Characterization of Mullites From Silicoaluminous Fly Ash Waste. Int. J. Appl. Nanotechnol. Res. (IJANR) 2020, 5, 10-25. [CrossRef]

100. Virendra, K.Y.; Suriyaprabha, R.; Inwati, G.K.; Gupta, N.; Singh, B.; Lal, C.; Kumar, P.; Godha, M.; Kalasariya, H. A Noble and Economical Method for the Synthesis of Low Cost Zeolites From Coal Fly Ash Waste. Adv. Mater. Process. Technol. 2021, 1-19. [CrossRef]

101. Wahyudi, A.; Kurniawan, W.; Husaini, A.A.M.; Hinode, H. Potential Application of Red Mud (Bauxite Residue) in Indonesia In Proceedings of the Seminar-Workshop on Utilization of Waste Materials, Manila, Philippines, 11-15 February 2015; pp. 57-62.

102. Balomenos, E.; Giannopoulou, I.; Panias, D.; Paspaliaris, I.; Perry, K.; Boufounos, D. Efficient and complete exploitation of the bauxite residue (red mud) produced in Bayer Process. In Proceedings of the European Metallurgical Conference (EMC, 2011), Duesseldorf, Germany, 26-29 June 2011; Volume 3, pp. 745-757.

103. Evans, K.; Nordheim, E.; Tsesmelis, K. Bauxite Residue Management. In Light Metals; Springer: Cham, Switzerland, 2012; pp. 63-66.

104. Paramguru, R.K.; Rath, C.; Misra, V.N. Trends in red mud utilization-A review Mineral Processing and Extractive Metall. Miner. Process. Extr. Metall. Rev. 2005, 26, 1-29.

105. Tan, R.B.; Khoo, H.H. An LCA study of a primary aluminum supply chain. J. Clean. Prod. 2005, 13, 607-618. [CrossRef]

106. Pogue, A.I.; Lukiw, W.J. The mobilization of aluminum into the biosphere. Front. Neurol. 2014, 5, 262. [CrossRef]

107. Abhilash, S.S.; Meshram, P.; Pandey, B.D.; Behera, K.; Satapathy, B.K. Redmud: A secondary resource for rare earth elements. In International bauxite, alumina and aluminium symposium. IBAAS Bind. 2014, 3, 148-162.

108. Moise, G.; Capota, P.; Enache, L.; Neagu, E.; Dragut, D.; Mihaescu, D.; Sarbu, A. Material composition and properties of red mud coming from domestic alumina processing plant. In Proceedings of the 20th International Symposium “Environment and Industry" SIMI 2017, Section Pollution Control and Monitoring, Bucharest, Romania, 28-29 September 2017; pp. 279-289.

109. Zhang, Y.; Wang, Y.; Meng, X.; Zheng, L.; Gao, J. The Suppression Characteristics of $\mathrm{NH}_{4} \mathrm{H}_{2} \mathrm{PO}_{4} /$ Red Mud Composite Powders on Methane Explosion. Appl. Sci. 2018, 8, 1433. [CrossRef]

110. Dentoni, V.; Grosso, B.; Massacci, G. Environmental Sustainability of the Alumina Industry in Western Europe. Sustainability 2014, 6, 9477-9493. [CrossRef]

111. Milacic, R.; Zuliani, T.; Ščančar, J. Environmental impact of toxic elements in red mud studied by fractionation and speciation procedures. Sci. Total. Environ. 2012, 426, 359-365. [CrossRef]

112. Li, X.B.; Xiao, W.; Liu, W.; Liu, G.H.; Peng, Z.H.; Zhou, Q.S.; Qi, T.G. Recovery of alumina and ferric oxide from Bayer red mud rich in iron by reduction sintering. Trans. Nonferrous Met. Soc. China 2009, 19, 1342-1347. [CrossRef]

113. Salman, A.D.; Juzsakova, T.; Rédey, Á.; Le, P.C.; Nguyen, X.C.; Domokos, E.; Abdullah, T.A.; Vagvolgyi, V.; Chang, S.W.; Nguyen, D.D. Enhancing the Recovery of Rare Earth Elements from Red Mud. Chem. Eng. Technol. 2021, 44, 1768-1774. [CrossRef]

114. Zhang, R.; Zheng, S.; Ma, S.; Zhang, Y. Recovery of alumina and alkali in Bayer red mud by the formation of andradite-grossular hydrogarnet in hydrothermal process. J. Hazard. Mater. 2011, 189, 827-835. [CrossRef]

115. Zhu, X.F.; Zhang, T.A.; Wang, Y.X.; Lü, G.Z.; Zhang, W.G. Recovery of alkali and alumina from Bayer red mud by the calcificationcarbonation method. Int. J. Miner. Metall. Mater. 2016, 23, 257-268. [CrossRef]

116. Meher, S.N. Alumina extraction from red mud by $\mathrm{CaCO}_{3}$ and $\mathrm{Na}_{2} \mathrm{CO}_{3}$ sinter process. Int. J. Chem. Stud. $2016,4,122-127$.

117. Wang, S.; Ang, H.M.; Tadé, M.O. Novel applications of red mud as coagulant, adsorbent and catalyst for environmentally benign processes. Chemosphere 2008, 72, 1621-1635. [CrossRef] [PubMed] 
118. Zouboulis, A.I.; Kydros, K.A. Use of red mud for toxic metals removal: The case of nickel. J. Chem. Technol. Biotechnol. 1993, 58, 95-101. [CrossRef]

119. Eamsiri, A.; Jackson, W.R.; Pratt, K.C.; Christov, V.; Marshall, M. Activated red mud as a catalyst for the hydrogenation of coals and of aromatic compounds. Fuel 1992, 71, 449-453. [CrossRef]

120. Hodge, W.W. Wastes Problems of the Iron and Steel Industries. Ind. Eng. Chem. 1939, 31, 1364-1380. [CrossRef]

121. Sarkar, S. Solid waste management in steel industry-challanges and opportunity. Int. J. Nucl. Energy Sci. Technol. 2015, 9, 884-887.

122. Anjum, M.; Miandad, R.; Waqas, M.; Gehany, F.; Barakat, M.A. Remediation of wastewater using various nanomaterials. Arab. J. Chem. 2019, 12, 4897-4919. [CrossRef]

123. Weidner, E.; Ciesielczyk, F. Removal of Hazardous Oxyanions from the Environment Using Metal-Oxide-Based Materials. Materials 2019, 12, 927. [CrossRef] [PubMed]

124. Akbarzadeh, A.; Samiei, M.; Davaran, S. Magnetic nanoparticles: Preparattion, physical properties and applications in biomedicine. Nanoscale Res. Lett. 2012, 7, 144. [CrossRef]

125. Tang, Z.; Ding, X.; Yan, X.; Dong, Y.; Liu, C. Recovery of Iron, Chromium, and Nickel from Pickling Sludge Using Smelting Reduction. Metals 2018, 8, 936. [CrossRef]

126. Tang, C.; Li, K.; Ni, W.; Fan, D. Recovering Iron from Iron Ore Tailings and Preparing Concrete Composite Admixtures. Minerals 2019, 9, 232. [CrossRef]

127. Zhang, G.F.; Yang, Q.R.; Yang, Y.D.; Wu, P.; McLean, A. Recovery of iron from waste slag of pyrite processing using reduction roasting magnetic separation method. Can. Metall. Q. 2013, 52, 153-159. [CrossRef]

128. Wang, Y.U.; Peng, Y.L.; Zheng, Y.J. Recovery of iron from waste ferrous sulphate by co-precipitation and magnetic separation. Trans. Nonferrous Met. Soc. China 2017, 27, 211-219.

129. Yadav, V.K.; Yadav, K.K.; Cabral-Pinto, M.M.S.; Choudhary, N.; Gnanamoorthy, G.; Tirth, V.; Prasad, S.; Khan, A.H.; Islam, S.; Khan, N.A. The Processing of Calcium Rich Agricultural and Industrial Waste for Recovery of Calcium Carbonate and Calcium Oxide and Their Application for Environmental Cleanup: A Review. Appl. Sci. 2021, 11, 4212. [CrossRef]

130. Ko, J.H.; Xu, Q.; Jang, Y.C. Emissions and Control of Hydrogen Sulfide at Landfills: A Review. Crit. Rev. Environ. Sci. Technol. 2015, 45, 2043-2083. [CrossRef]

131. Xu, Q.; Townsend, T.; Bitton, G. Inhibition of hydrogen sulfide generation from disposed gypsum drywall using chemical inhibitors. J. Hazard. Mater. 2011, 191, 204-211. [CrossRef]

132. De Beer, M.; Doucet, F.J.; Maree, J.; Liebenberg, L. Synthesis of high-purity precipitated calcium carbonate during the process of recovery of elemental sulphur from gypsum waste. Waste Manag. 2015, 46, 619-627. [CrossRef]

133. Cuesta Mayorga, I.; Astilleros, J.M.; Fernández-Díaz, L. Precipitation of CaCO3 Polymorphs from Aqueous Solutions: The Role of $\mathrm{pH}$ and Sulphate Groups. Minerals 2019, 9, 178. [CrossRef]

134. Sufang, W.U.; Peiqiang, L.A.N. Method for Preparing a Nano-Calcium Carbonate Slurry from Waste Gypsum as Calciumsource, the Product and Use Thereof. United States Patent Application Publication. U.S. Patent 8,846,562, 30 September 2014.

135. Okumura, S.; Mihara, N.; Kamiya, K.; Ozawa, S.; Onyango, M.S.; Kojima, Y.; Iwashita, T. Recovery of CaO by Reductive Decomposition of Spent Gypsum in a $\mathrm{CO}-\mathrm{CO}_{2}-\mathrm{N}_{2}$ Atmosphere. Ind. Eng. Chem. Res. 2003, 42, 6046-6052. [CrossRef]

136. Ramachandran, N.; Maniam, G. Regeneration of calcium oxide (CaO) from waste gypsum via two-step reaction. In Proceedings of the 8th Malaysian Technical Universities Conference on Engineering \& Technology (MUCET 2014), Malacca, Malaysia, 10-11 November 2014.

137. Mbhele, N.R.; Van Der Merwe, W.; Maree, J.; Theron, D. Recovery of sulphur from waste gypsum. In Proceedings of the Abstracts of the International Mine Water Conference, Mpumalanga, South Africa, 19-23 October 2009; pp. 622-630.

138. Nagrale, S.D.; Hajare, H.; Modak, R. Utilization of rice husk ash. Int. J. Eng. Res. Appl. 2012, 2, 42.

139. Yadav, V.K.; Choudhary, N.; Tirth, V.; Kalasariya, H.; Gnanamoorthy, G.; Algahtani, A.; Yadav, K.K.; Soni, S.; Islam, S.; Yadav, S.; et al. A Short Review on the Utilization of Incense Sticks Ash as an Emerging and Overlooked Material for the Synthesis of Zeolites. Crystals 2021, 11, 1255. [CrossRef]

140. Tomar, R.; Kishore, K.; Singh Parihar, H.; Gupta, N. A comprehensive study of waste coconut shell aggregate as raw material in concrete. Mater. Today Proc. 2021, 44, 437-443. [CrossRef]

141. Channoy, C.; Maneewan, S.; Punlek, C.; Chirarattananon, S. Preparation and Characterization of Silica Gel from Bagasse Ash. In Advanced Materials Research; Trans Tech Publications Ltd.: Zurich, Switzerland, 2018; Volume 1145, pp. 44-48. [CrossRef]

142. Balasubramaniam, P.; Peera, S.P.G.; Mahendran, P.P.; Tajuddin, A. Release of silicon from soil applied with graded levels of fly ash with silicate solubilizing bacteria and farm yard manure. In Proceedings of the 5th International Conference on Silicon in Agriculture, Beijing, China, 13-18 September 2011.

143. Yadav, V.K.; Malik, P.; Khan, A.H.; Pandit, R.; Hasan, M.A.; Cabral-Pinto, M.M.S.; Islam, S.; Suriyaprabha, R.; Yadav, K.K.; Dinis, A.; et al. Recent Advances on Properties and Utility of Nanomaterials Generated from Industrial and Biological Activities. Crystals 2021, 11, 634. [CrossRef]

144. Nayak, P.P.; Datta, A. Synthesis of $\mathrm{SiO}_{2}-$ Nanoparticles from Rice Husk Ash and its Comparison with Commercial Amorphous Silica through Material Characterization. Silicon 2021, 13, 1209-1214. [CrossRef]

145. Mokhena, T.C.; Mochane, M.J.; Motaung, T.E.; Linganiso, L.Z.; Thekisoe, O.M.; Songca, S. Sugarcane Bagasse and Cellulose Polymer Composites. In Sugarcane-Technology and Research; IntechOpen: London, UK, 2018. 
146. Schettino, M.A.S.; Holanda, J.N.F. Characterization of sugarcane bagasse ash waste for its use in ceramic floor tile. Procedia Mater. Sci. 2015, 8, 190-196. [CrossRef]

147. Drummond, A.R.F.; Drummond, W.I. Pyrolysis of Sugar Cane Bagasse in a Wire-Mesh Reactor. Ind. Eng. Chem. Res. 1996, 35, 1263-1268. [CrossRef]

148. Harish, R.; Aru, A.; Ponnusami, V. Recovery of silica from various low cost precursors for the synthesis of silica gel. Pharm. Lett. 2015, 7, 208-213.

149. Norsuraya, S.; Hamzah, F.; Rahmat, N. Sugarcane Bagasse as a Renewable Source of Silica to Synthesize Santa Barbara Amorphous15 (SBA-15). Procedia Eng. 2016, 148, 839-846. [CrossRef]

150. Rovani, S.; Santos, J.J.; Corio, P.; Fungaro, D.A. Highly Pure Silica Nanoparticles with High Adsorption Capacity Obtained from Sugarcane Waste Ash. ACS Omega 2018, 3, 2618-2627. [CrossRef] [PubMed]

151. Manjula, C.; Kukkamgai, S.; Rahman, S.; Rajesh, M.K. Characterization of Kuttiyadi ecotype of coconut (Cocos nucifera L.) using morphological and microsatellite markers. J. Plant. Crops 2014, 42, 301-315.

152. Omer, A.M. Agricultural residues for future energy option in Sudan: An analysis. Ann. Adv. Chem. 2016, 2, 17-31. [CrossRef]

153. Anuar, M.F.; Fen, Y.W.; Zaid, M.H.M.; Matori, K.A.; Khaidir, R.E.M. Synthesis and structural properties of coconut husk as potential silica source. Results Phys. 2018, 11,1-4. [CrossRef]

154. Rodgers, K.; Hursthouse, A.; Cuthbert, S. The Potential of Sequential Extraction in the Characterisation and Management of Wastes from Steel Processing: A Prospective Review. Int. J. Environ. Res. Public Health 2015, 12, 11724-11755. [CrossRef] [PubMed]

155. Sivasubramanian, S.; Sravanthi, K. Synthesis and characterisation of silica nano particles from coconut shell. Int. J. Pharma Bio Sci. 2015, 6, 530-536.

156. Melati, A.; Hidayati, E. Synthesis and characterization of carbon nanotube from coconut shells activated carbon. J. Phys. Conf. Ser. 2016, 694, 012073. [CrossRef]

157. Adewumi, G.A.; Revaprasadu, N.; Eloka-Eboka, A.C.; Inambo, F.L.; Gervas, C. A facile low-cost synthesis of carbon nanosphere from coconut fibre. In Proceedings of the World Congress on Engineering and Computer Science, San Francisco, CA, USA, 25-27 October 2017; pp. 577-582.

158. Hakim, Y.Z.; Yulizar, Y.; Nurcahyo, A.; Surya, M. Green Synthesis of Carbon Nanotubes from Coconut Shell Waste for the Adsorption of $\mathrm{Pb}(\mathrm{II})$ Ions. Acta Chim. Asiana 2018, 1, 6-10. [CrossRef]

159. Kumar, S.; Bhatt, B. Status and production technology of maize. In Status of Agricultural Development in Eastern India; Bhatt, B.P., Sikka, A., Mukharjee, J., Islam, A., Dey, A., Eds.; ICAR RCER: Patna, India, 2012; pp. 151-167.

160. Berber-Villamar, N.K.; Netzahuatl-Muñoz, A.R.; Morales-Barrera, L.; Chávez-Camarillo, G.M.; Flores-Ortiz, C.M.; Cristiani-Urbina, E. Corncob as an effective, eco-friendly, and economic biosorbent for removing the azo dye Direct Yellow 27 from aqueous solutions. PLoS ONE 2018, 13, e0196428. [CrossRef]

161. Sun, Y.; Webley, P.A. Preparation of activated carbons from corncob with large specific surface area by a variety of chemical activators and their application in gas storage. Chem. Eng. J. 2010, 162, 883-892. [CrossRef]

162. Sabir, M.; Zia-ur-Rehman, M.; Hakeem, K.R.; Saifullah, U. Phytoremediation of Metal-Contaminated Soils Using Organic Amendments: Prospects and Challenges. In Soil Remediation and Plants; Hakeem, K.R., Sabir, M., Öztürk, M., Mermut, A.R., Eds.; Academic Press: London, UK, 2015; pp. 503-523.

163. Dias, J.M.; Alvim-Ferraz, M.C.; Almeida, M.F.; Rivera-Utrilla, J.; Sánchez-Polo, M. Waste Materials for Activated Carbon Preparation and Its Use in Aqueous-phase Treatment: A Review. J. Environ. Manag. 2007, 85, 833-846. [CrossRef]

164. Wang, J.; Kaskel, S. KOH activation of carbon-based materials for energy storage. J. Mater. Chem. 2012, 22, 23710-23725. [CrossRef]

165. Rashed, M.N. Adsorption Technique for the Removal of Organic Pollutants from Water and Wastewater. Org. Pollut. Monit. Risk Treat. 2013, 7, 167-194.

166. Tsai, W.T.; Chang, C.Y.; Wang, S.Y.; Chang, C.F.; Chien, S.F.; Sun, H.F. Utilization of agricultural waste corn cob for the preparation of carbon adsorbent. J. Environ. Sci. Health 2011, 36, 677-686. [CrossRef]

167. Tsai, W.T.; Chang, C.Y.; Wang, S.Y.; Chang, C.F.; Chien, S.F.; Sun, H.F. Preparation of activated carbons from corn cob catalyzed by potassium salts and subsequent gasification with $\mathrm{CO}_{2}$. Bioresour. Technol. 2001, 78, 203-208. [CrossRef]

168. Kaźmierczak-Raźna, J.; Nowicki, P.; Pietrzak, R. Sorption properties of activated carbons obtained from corn cobs by chemical and physical activation. Adsorption 2013, 19, 273-281. [CrossRef]

169. Hashemian, S.; Salari, K.; Yazdi, Z.A. Preparation of activated carbon from agricultural wastes (almond shell and orange peel) for adsorption of 2-pic from aqueous solution. J. Ind. Eng. Chem. 2014, 20, 1892-1900. [CrossRef]

170. Ratan, J.K.; Kaur, M.; Adiraju, B. Synthesis of activated carbon from agricultural waste using a simple method: Characterization, parametric and isotherms study. Mater. Today Proc. 2018, 5, 3334-3345. [CrossRef]

171. Zhu, T.; Dittrich, M. Carbonate Precipitation through Microbial Activities in Natural Environment, and Their Potential in Biotechnology: A Review. Front. Bioeng. Biotechnol. 2016, 4, 4. [CrossRef]

172. Al Omari, M.M.H.; Rashid, I.S.; Qinna, N.A.; Jaber, A.M.; Badwan, A.A. Calcium Carbonate. In Profiles of Drug Substances, Excipients and Related Methodology; Brittain, H.G., Ed.; Academic Press: London, UK, 2016; Volume 41, pp. 31-132.

173. Cho, S.H.; Park, J.K.; Lee, S.K.; Joo, S.M.; Kim, I.H.; Ahn, J.-W.; Kim, H. Synthesis of Precipitated Calcium Carbonate Using a Limestone and its Application in Paper Filler and Coating Color. In Materials Science Forum; Trans Tech Publications Ltd.: Zurich, Switzerland, 2007; pp. 881-884. 
174. Huwald, E. Calcium carbonate-pigment and filler. In Calcium Carbonate: From the Cretaceous Period into the 21st Century; Tegethoff, F.W., Ed.; Birkhäuser Basel: Basel, Switzerland, 2001; pp. 160-170.

175. Boyjoo, Y.; Pareek, V.K.; Liu, J. Synthesis of micro and nano-sized calcium carbonate particles and their applications. J. Mater. Chem. A 2014, 2, 14270-14288. [CrossRef]

176. Thomas, S.; Sharma, H.; Mishra, P.; Talegaonkar, S. Ceramic Nanoparticles: Fabrication Methods and Applications in Drug Delivery. Curr. Pharm. Des. 2015, 21, 6165-6188. [CrossRef] [PubMed]

177. Dizaj, S.M.; Barzegar-Jalali, M.; Zarrintan, M.H.; Adibkia, K.; Lotfipour, F. Calcium carbonate nanoparticles as cancer drug delivery system. Expert Opin. Drug Deliv. 2015, 12, 1649-1660. [CrossRef]

178. Hua, K.H.; Wang, H.C.; Chung, R.S.; Hsu, J.C. Calcium carbonate nanoparticles can enhance plant nutrition and insect pest tolerance. J. Pestic. Sci. 2015, 40, 208-213. [CrossRef]

179. Aframehr, W.M.; Molki, B.; Heidarian, P.; Behzad, T.; Sadeghi, M.; Bagheri, R. Effect of calcium carbonate nanoparticles on barrier properties and biodegradability of polylactic acid. Fibers Polym. 2017, 18, 2041-2048. [CrossRef]

180. Trushina, D.B.; Bukreeva, T.V.; Kovalchuk, M.V.; Antipina, M.N. CaCO3 vaterite microparticles for biomedical and personal care applications. Mater. Sci. Eng. C 2014, 45, 644-658. [CrossRef]

181. Grasby, S.E. Naturally precipitating vaterite $\left(\mu-\mathrm{CaCO}_{3}\right)$ spheres: Unusual carbonates formed in an extreme environment. Geochim. Et Cosmochim. Acta 2013, 67, 1659-1666. [CrossRef]

182. De Leeuw, N.H.; Parker, S.C. Surface Structure and Morphology of Calcium Carbonate Polymorphs Calcite, Aragonite, and Vaterite: An Atomistic Approach. J. Phys. Chem. B 1998, 102, 2914-2922. [CrossRef]

183. Buasri, A.; Chaiyut, N.; Loryuenyong, V.; Worawanitchaphong, P.; Trongyong, S. Calcium Oxide Derived from Waste Shells of Mussel, Cockle, and Scallop as the Heterogeneous Catalyst for Biodiesel Production. Sci. World J. 2013, 2013, 7. [CrossRef] [PubMed]

184. Dewangan, S.; Chakrabarty, R.; Zielinska, B.; Pervez, S. Emission of volatile organic compounds from religious and ritual activities in India. Environ. Monit. Assess. 2013, 185, 9279-9286. [CrossRef] [PubMed]

185. Hazarika, P.; Dutta, N.B.; Biswas, S.C.; Dutta, R.C.; Jayaraj, R.S.C. Status of agarbatti industry in India with special reference to Northeast. Int. J. Adv. Res. Biol. Sci. 2018, 5, 173-186.

186. Settimo, G.; Tirler, W. Incense, sparklers and cigarettes are significant contributors to indoor benzene and particle levels. Ann. Ist. Super. Sanita. 2015, 51, 28-33.

187. Abdulrahman, I.; Tijani, H.I.; Mohammed, B.A.; Saidu, H.; Yusuf, H.; Jibrin, M.N.; Mohammed, S. From garbage to biomaterials:an overview on eggshell based hydroxyapatite. J. Mater. 2014, 2014, 802467.

188. Asri, N.P.; Podjojono, B.; Fujiani, R. Utilization of eggshell waste as low-cost solid base catalyst for biodiesel production from used cooking oil. In IOP Conference Series: Earth and Environmental Science; IOP Publishing: Bristol, UK, 2017; Volume 67, p. 012021.

189. Ummartyotin, S.; Tangnorawich, B. Utilization of eggshell waste as raw material for synthesis of hydroxyapatite. Colloid Polym. Sci. 2015, 293, 2477-2483. [CrossRef]

190. Hassan, T.; Rangari, V.; Rana, R.; Jeelani, S. Sonochemical effect on size reduction of CaCO3 nanoparticles derived from waste eggshells. Ultrason. Sonochem. 2013, 20, 1308-1315. [CrossRef]

191. Hassan, T.; Rangari, V.; Jeelani, S. Sonochemical synthesis and characterisation of bio-based hydroxyapatite nanoparticles. Int. J. Nano Biomater. 2014, 5, 103-112. [CrossRef]

192. Hariharan, M.; Varghese, N.; Cherian, A.B.; Paul, J. Synthesis and characterisation of CaCO3 (Calcite) nano particles from cockle shells using chitosan as precursor. Int. J. Sci. Res. Publ. 2014, 4, 5.

193. Channappa, B.; Kambalagere, Y.; Mahadevan, K.M.; Narayanappa, M. Synthesis of Calcium Oxide Nanoparticles and Its Mortality Study on Fresh Water Fish Cyprinus Carpio. IOSR J. Environ. Sci. Toxicol. Food Technol. 2016, 10, 55-60.

194. Mirghiasi, Z.; Bakhtiari, F.; Darezereshki, E.; Esmaeilzadeh, E. Preparation and characterization of CaO nanoparticles from $\mathrm{Ca}(\mathrm{OH})_{2}$ by direct thermal decomposition method. J. Ind. Eng. Chem. 2014, 20, 113-117. [CrossRef]

195. Roy, A.; Bhattacharya, J. Microwave-assisted synthesis and characterization of CaO nanoparticles. Int. J. Nanosci. 2011, 10, 413-418. [CrossRef]

196. Darcanova, O.; Beganskienè, A.; Kareiva, A. Sol-gel synthesis of calcium nanomaterial for paper conservation. Chemija 2015, 26, 25-31.

197. Ali, S.; Butt, A.; Ejaz, S.; Baron, C.J.; Ikram, D.M. CaO nanoparticles as a potential drug delivery agent for biomedical applications. Dig. J. Nanomater. Biostructures 2015, 10, 799.

198. Sadeghi, M.; Husseini, M.H. A Novel Method for the Synthesis of CaO Nanoparticle for the Decomposition of Sulfurous Pollutant. J. Appl. Chem. Res. 2013, 7, 10.

199. Liu, T.; Zhu, Y.; Zhang, X.; Zhang, T.; Zhang, T.; Li, X. Synthesis and characterization of calcium hydroxide nanoparticles by hydrogen plasma-metal reaction method. Mater. Lett. 2010, 64, 2575-2577. [CrossRef]

200. Yorug, A.H.; Ipek, Y. Sonochemical Synthesis of Hydroxyapatite Nanoparticles with Different Precursor Reagents. Acta Phys. Pol.-Ser. A Gen. Phys. 2012, 121, 230.

201. Mohd Abd Ghafar, S.L.; Hussein, M.Z.; Abu Bakar Zakaria, Z. Synthesis and Characterization of Cockle Shell-Based Calcium Carbonate Aragonite Polymorph Nanoparticles with Surface Functionalization. J. Nanoparticles 2017, 2017, 12. [CrossRef]

202. Mohadi, R.; Anggraini, K.; Riyanti, F.; Lesbani, A. Preparation Calcium Oxide from Chicken Eggshells. Sriwijaya J. Environ. 2016, 1, 32-35. [CrossRef] 
203. Mulopo, L.; Radebe, V. Recovery of calcium carbonate from waste gypsum and utilization for remediation of acid mine drainage from coal mines. Water Sci. Technol. 2012, 66, 1296-1300. [CrossRef] [PubMed]

204. Render, D.; Samuel, T.; King, H.; Vig, M.; Jeelani, S.; Babu, R.J.; Rangari, V. Biomaterial-Derived Calcium Carbonate Nanoparticles for Enteric Drug Delivery. J. Nanomater. 2016, 2016, 8. [CrossRef] [PubMed]

205. Tangboriboon, N.; Kunanuruksapong, R.; Sirivat, A. Preparation and properties of calcium oxide from eggshells via calcination Mater. Sci.-Pol. 2012, 30, 313-322. [CrossRef]

206. Jirimali, H.D.; Chaudhari, B.C.; Khanderay, J.C.; Joshi, S.A.; Singh, V.; Patil, A.M.; Gite, V.V. Waste Eggshell-Derived Calcium Oxide and Nanohydroxyapatite Biomaterials for the Preparation of LLDPE Polymer Nanocomposite and Their Thermomechanical Study. Polym. Plast. Technol. Eng. 2018, 57, 804-811. [CrossRef] 